\title{
Recovery of Banana Waste-Loss from Production and Processing: A Contribution to a Circular Economy
}

\author{
Sasha Alzate Acevedo ${ }^{1}{ }^{\mathbb{D}}$, Álvaro José Díaz Carrillo ${ }^{1} \mathbb{(}$, Edwin Flórez-López ${ }^{2} \mathbb{C}$ \\ and Carlos David Grande-Tovar ${ }^{3, * \text { (D) }}$ \\ 1 Programa de Ingeniería Agroindustrial, Facultad de Ingeniería, Universidad del Atlántico, Puerto 081007, Colombia; \\ salzatea@mail.uniatlantico.edu.co (S.A.A.); alvarojosediaz@est.uniatlantico.edu.co (Á.J.D.C.) \\ 2 Grupo de Investigación en Química y Biotecnología QUIBIO, Universidad Santiago de Cali, Calle 5 No 62-00, \\ Cali 760035, Colombia; edwin.florez00@usc.edu.co \\ 3 Grupo de Investigación en Fotoquímica y Fotobiología, Universidad del Atlántico, Carrera 30 \# 8-49, \\ Puerto Colombia 081007, Colombia \\ * Correspondence: carlosgrande@mail.uniatlantico.edu.co; Tel.: +57-5-3599484
}

check for updates

Citation: Alzate Acevedo, S.; Díaz Carrillo, Á.J.; Flórez-López, E.; Grande-Tovar, C.D. Recovery of Banana Waste-Loss from Production and Processing: A Contribution to a Circular Economy. Molecules 2021, 26, 5282. https://doi.org/10.3390/ molecules 26175282

Academic Editors: Nicola Marchetti and Roberta Costi

Received: 30 July 2021

Accepted: 28 August 2021

Published: 31 August 2021

Publisher's Note: MDPI stays neutral with regard to jurisdictional claims in published maps and institutional affiliations.

Copyright: (c) 2021 by the authors. Licensee MDPI, Basel, Switzerland. This article is an open access article distributed under the terms and conditions of the Creative Commons Attribution (CC BY) license (https:// creativecommons.org/licenses/by/ $4.0 /)$.

\begin{abstract}
Banana is a fruit grown mainly in tropical countries of the world. After harvest, almost $60 \%$ of banana biomass is left as waste. Worldwide, about 114.08 million metric tons of banana waste-loss are produced, leading to environmental problems such as the excessive emission of greenhouse gases. These wastes contain a high content of paramount industrial importance, such as cellulose, hemicellulose and natural fibers that various processes can modify, such as bacterial fermentation and anaerobic degradation, to obtain bioplastics, organic fertilizers and biofuels such as ethanol, biogas, hydrogen and biodiesel. In addition, they can be used in wastewater treatment methods by producing low-cost biofilters and obtaining activated carbon from rachis and banana peel. Furthermore, nanometric fibers commonly used in nanotechnology applications and silver nanoparticles useful in therapeutic cancer treatments, can be produced from banana pseudostems. The review aims to demonstrate the contribution of the recovery of banana production waste-loss towards a circular economy that would boost the economy of Latin America and many other countries of emerging economies.
\end{abstract}

Keywords: banana waste-loss; biofuels; circular economy; global banana production; metabolite recovery

\section{Introduction}

The food sector is divided into different industries, such as the pasta industry, as well as fruits and vegetables, fish, meat and beverages (Figure 1), transforming agricultural raw materials into value-added products [1].

Fruits and vegetables are vital in the daily diet of humans, whose demand is constantly growing due to the increase in population and changes in eating habits. According to the Food and Agriculture Organization of the United Nations (FAO), the world trade of mainly tropical fruits reached a maximum of 7.7 million tons in 2019 , an increase of $6.4 \%$ (465,000 tons), compared to the previous year [2].

Banana is a tropical fruit grown in more than 130 countries. It is the second mostproduced fruit after citrus, contributing around $16 \%$ of world fruit production and the fourth most important food crop after rice, wheat and corn. Banana is very nutritious and digests better than many other fruits. Their vast consumption is due to their sensory characteristics and attractive texture and flavor. In addition, it has a high calorie content, with a small amount of fat, and is an excellent source of dietary fiber, vitamin C, vitamin B6 and manganese [3]. The phenols present in banana fruit are the primary antioxidants that provide health benefits. Several phenolics are present in bananas, such as gallic acid, catechin, epicatechin, tannins and anthocyanins [4]. 


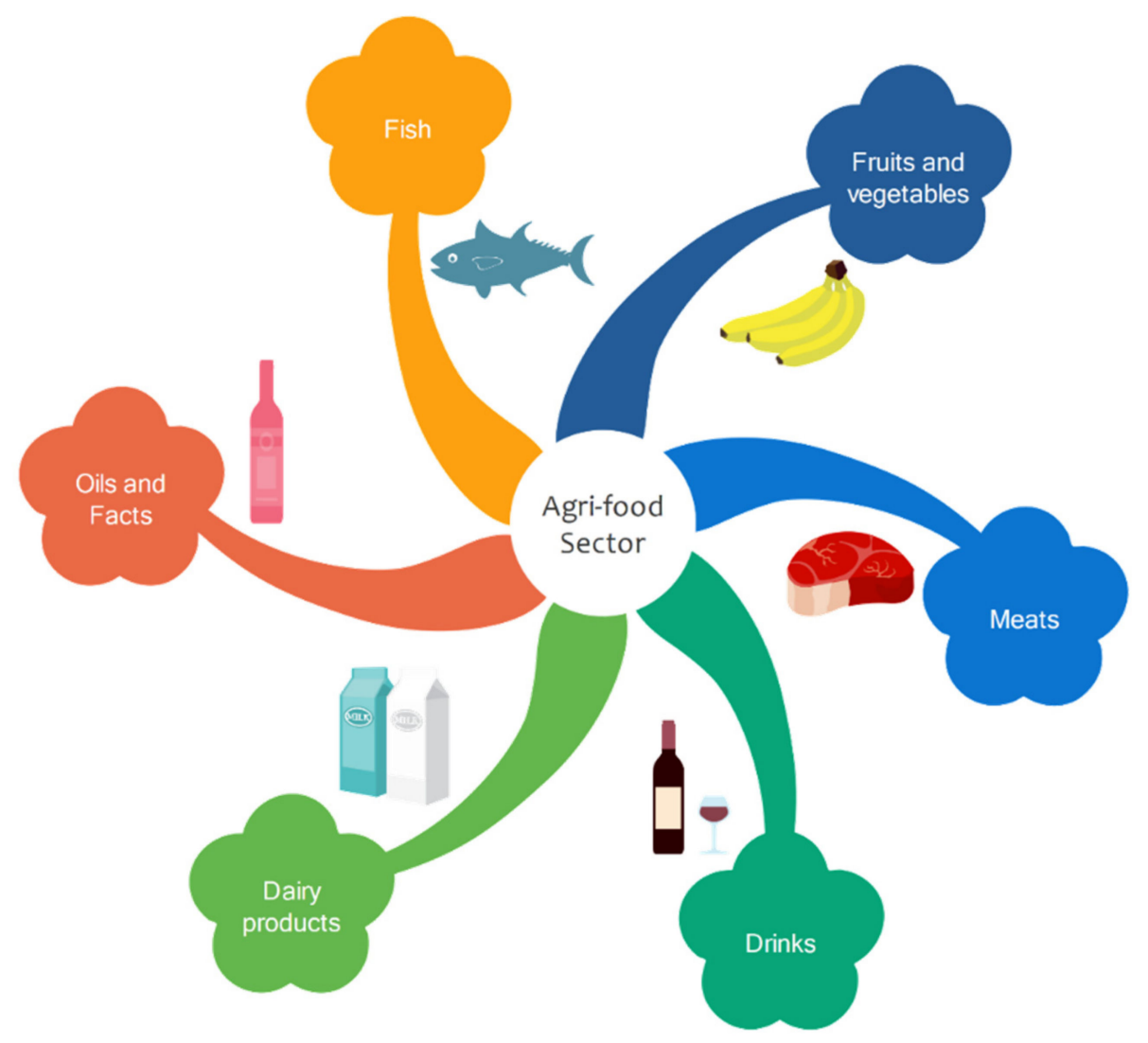

Figure 1. Different industries in the agri-food sector.

Diets rich in fruits and vegetables with phenols are associated with a lower risk of cancer and heart disease [5]. Phenolic compounds have been used effectively as functional ingredients in foods to prevent lipid oxidation and prevent mold and bacterial growth [6]. Therefore, the banana's recovery from these secondary metabolites can generate functional ingredients and add value to the banana industry [7].

In 2019, India led banana production with 30.4 million tons, followed by China with 11.6 million tons (Figure 2). The third place was for Indonesia with 7.2 million tons, while Brazil ranked fourth with 6.8 million tons, and the country with the fifth highest production index was Ecuador, with 6.5 million tons produced [8].

According to the United Nations Food and Agriculture Organization (2020) report, banana production had significant growth in the last few years. The market analysis determined that exports reached 20.2 million tons in 2019, due to the growth of banana production in Ecuador and the Philippines, with an estimated growth for 2028 of 135 million tons [9].

According to data from the Ministry of Agriculture and Livestock, total exports of bananas and their products in Ecuador from January to July 2019 were worth two billion dollars, representing $51 \%$ of the agricultural production [10].

In 2019, 51,227 hectares of bananas were planted in Colombia. Colombian banana exports were estimated at USD 852.8 million, while those exported to Belgium were worth USD 204.8 million and those to the United Kingdom were worth USD 169.6 million. About USD 149 million-worth were exported to the United States, and USD 124.8 million-worth to Italy [11].

Several countries produced and exported bananas in Europe in 2019, such as the Netherlands, Belgium and Germany, with revenues of USD 790.6 million, USD 782.1 million and USD 242.1 million, respectively [12].

In Asia, banana exports reached a maximum of 5.1 million tons, representing an increase of $42 \%$ compared to the 3.5 million tons exported in 2018 [13]. The Philippines has the highest amount of exports of bananas in the Asian continent, and the third place 
globally (Figure 2). According to preliminary figures provided by the Philippine Statistics Authority (PSA), the export of bananas from this country reached 3.59 million metric tons in 2020, which was $18.35 \%$ less than the 4.4 million tons reported in 2019 [14]. Despite a labor shortage, supply chains continue to function despite constraints stemming from measures taken by governments to contain the spread of the pandemic. Sales were affected, however, as was the case with the Philippines [15].

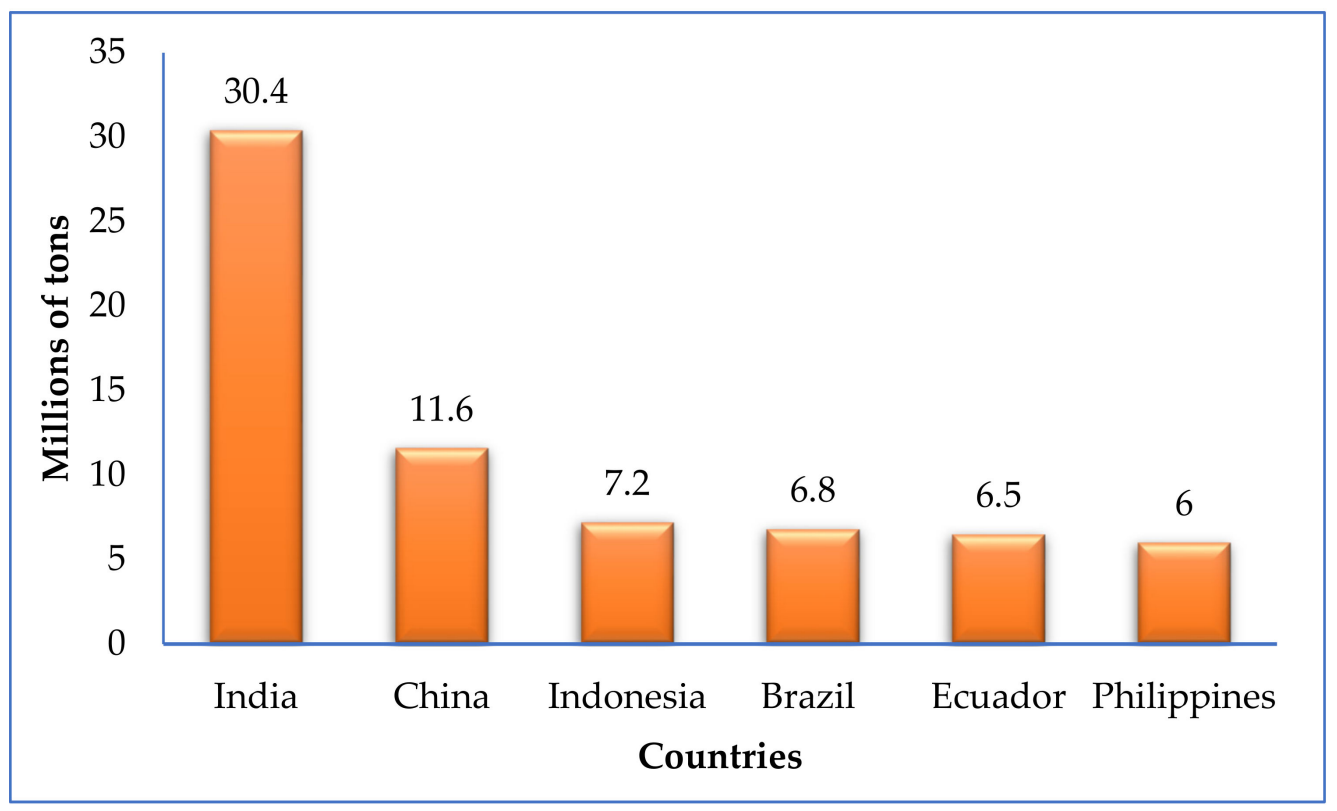

Figure 2. World banana production in 2019 [8,13].

The leading sales from the banana industry derive from fresh banana sales, while the processing rate is less than $20 \%$. Therefore, banana processing has excellent development potential due to the generation and use of processing waste-loss in new production chains. The advanced processing technology is the driving force to improve the added value of commodities and the resource utilization rate of bananas [16].

The banana industry during its production cycle generates large volumes of solid waste-loss derived from maintenance and harvesting processes, highlighting the rachis, pseudostems, leaves and banana peel, which can be used in different processes, such as packaging products and other applications based on bioplastics, thus contributing to the implementation of a circular economy [17].

There are different studies on the processing of bananas and the application of their waste-loss in new production processes [18-21]. Even so, most of them focus on a single waste, limiting the knowledge and the potential to create new production chains from a natural source. This review offers a comprehensive view of the agro-industrial waste produced in banana processing, potential uses and application in different processes such as biofuel production, wastewater treatment, nanotechnology, bioplastics production as an alternative and an incentive for the development of a circular economy.

The circular economy (CE) can be defined as an economic model based on the efficient use of resources through the minimization of waste, long-term value retention, reduction of primary resources and closed production cycles within the limits of socio-environmental policies [22]. The traditional model is based on a linear consumption where raw materials are extracted and processed into finished products and waste [23]. The circular economy aims to prevent the depletion of resources, close the circuits of energy and materials. The $\mathrm{CE}$ implementation will improve sales for companies and quality for consumers while integrating agents and cities, regions and governments in a sustainable and lasting model (Figure 3) [24]. 


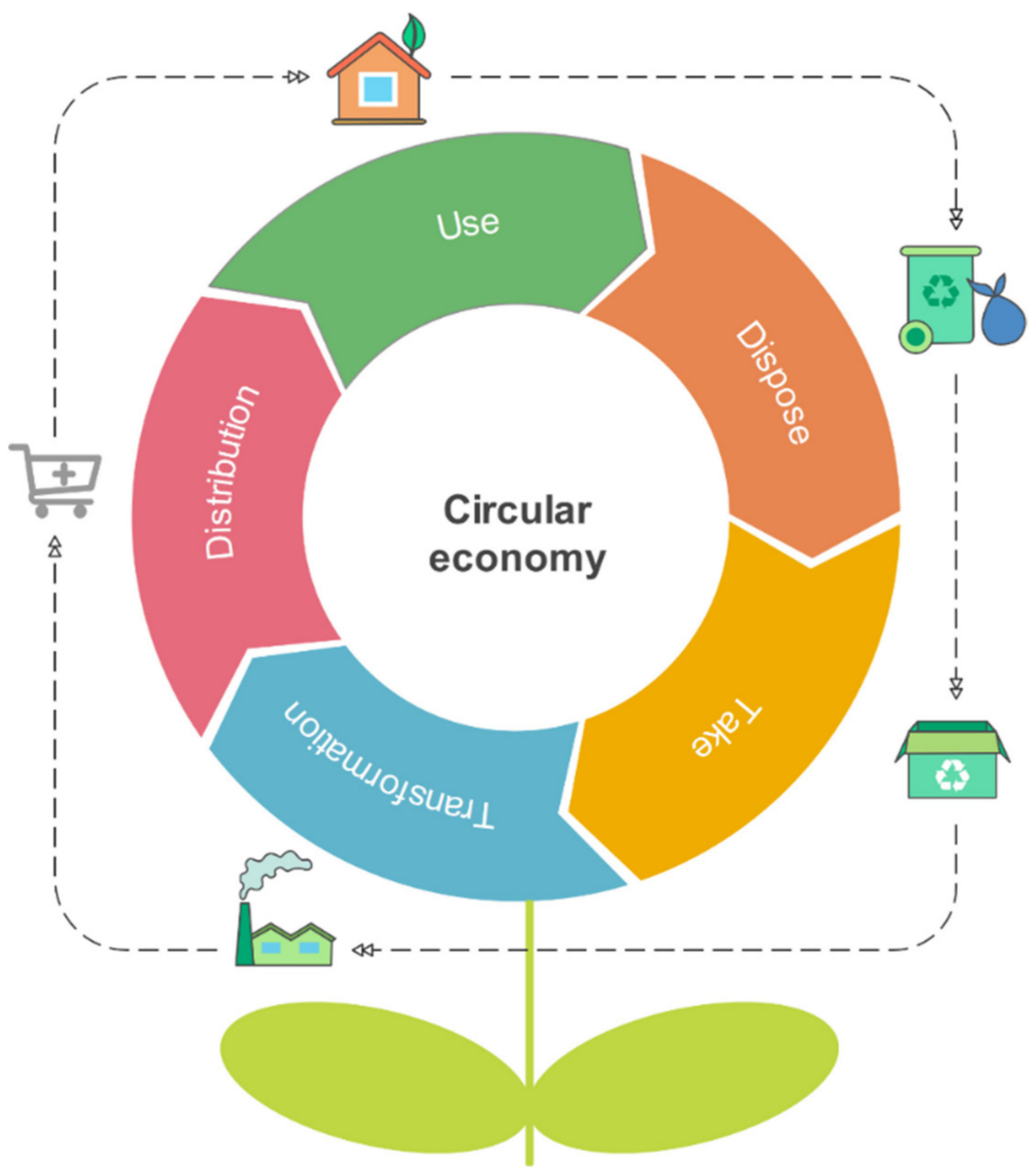

Figure 3. Scheme for a circular economy cycle.

The internal circles of production, reuse and reconditioning demand fewer resources and energy and are more economical than conventional recycling [25]. Climate change is the most imminent environmental problem facing the world. Rising global temperatures have essential effects on human life, food chains, ecosystems and wildlife [26].

An additional benefit of applying a circular economy would help organizations hedge against volatility in commodity prices and rebalance flows of goods, scrap and used products [27]. The Ellen MacArthur Foundation estimates that by 2030 a shift to a CE could reduce resource expenditures in the European Union (UE) by 600 billion euros annually, improving resource productivity by up to $3 \%$ per year and generating an annual net profit of 1.8 billion euros [28].

The review aims to demonstrate the contribution of banana production waste-loss towards the implementation of the circular economy by proposing several possible applications (biofuels, water treatment, bioplastic, nanotechnology and organic fertilizers) in order to provide the reader with innovative, sustainable and low-cost ideas that will allow relief in the global economy.

\section{Banana}

Banana is a large-scale, evergreen herbaceous plant belonging to the Zingiberales order, Musaceae family and Musa genus, with high calcium, magnesium and high assimilation of nitrogen emissions [29]. The banana is a fruit with variable qualities, based on size, color and firmness, generally curved and fleshy, covered with green skin, yellow after maturation and brown when ripe. The fruit grows in cones from the plant's top, up to $15 \mathrm{~m}$ between 80 to 180 days [30]. 
In general, bananas have more than 50 species and dozens of hybrids, large and rhizomatous underground stems, from which their large leaves with powerfully spirally arranged pods start, giving the shape of a false stem (pseudostem, Figure 4).

It belongs to the Musaceae family, order Scitamineae. This family is made up of the Musa and Ensete gender, monocotyledonous plants, of intraspecific and interspecific crosses between Musa acuminata Colla (genome A) and Musa balbisiana Colla (genome B) [31]. Currently, banana classification is based on various morphological variations that help in the differentiation of landrace varieties of dessert bananas (AA, AAA, AAB), cooking bananas (AAA, $\mathrm{AAB}, \mathrm{ABB}$ ) and cooking bananas (AAB) [32]. To illustrate this classification more clearly, Table 1 groups together varieties of bananas such as Cavendish or Gros Michel, which usually are produced in countries with a good production index, such as India, the Philippines and Ecuador.

\section{Chemical Composition of Banana}

Banana contains sugars, acids, vitamin $C$, amino acids and pectin that form the fruit's soluble solids content and vary according to the variety grown and the degree of maturity [42]. During the ripening process, ethylene production is induced, which stimulates the production of the enzyme amylase, and breaks down starch into sugar. At the same time, it initiates the synthesis of the enzyme pectinase to act on the pectin between the cells of the pulp, allowing the softening of the plant tissues [43].

Table 1. Classification of banana varieties based on morphological differences.

\begin{tabular}{|c|c|c|c|c|}
\hline Producing Country & Variety & Genotype & Subgroup & References \\
\hline \multirow{4}{*}{ Ecuador } & Williams & AAA & Gros Michel & \multirow{4}{*}[34,35]{} \\
\hline & Dwarf Cavendish & AAA & Cavendish & \\
\hline & Maqueño & $\mathrm{AAB}$ & Red & \\
\hline & Gros Michel Highgate & AAA & Gros Michel & \\
\hline \multirow{3}{*}{ Philippines } & Saba & $\mathrm{ABB}$ & Saba & \multirow{3}{*}[36,37]{} \\
\hline & Cavendish & AAA & Cavendish & \\
\hline & Lakatan & AAA & Lakatan & \\
\hline \multirow{4}{*}{ Colombia } & Banana Valery & AAA & Cavendish & \multirow{4}{*}{ [38] } \\
\hline & Hartón Enano & $\mathrm{AAB}$ & Plantain & \\
\hline & Bocadillo del Quindío & AA & Sucrier & \\
\hline & Guineo Común & AAAae & Lujujira & \\
\hline \multirow{4}{*}{ India } & Robusta & AAA & Cavendish & \multirow{4}{*}[39,40]{} \\
\hline & Palayankodan & $\mathrm{AAB}$ & Mysore & \\
\hline & Nendran & $\mathrm{AAB}$ & Cavendish & \\
\hline & Red banana & AAA & Red & \\
\hline \multirow{3}{*}{ Perú } & Williams & AAA & Cavendish & \multirow{3}{*}{ [41] } \\
\hline & FHIA-17 & AAAA & Non-defined & \\
\hline & Cavendish Valery & AAA & Cavendish & \\
\hline
\end{tabular}




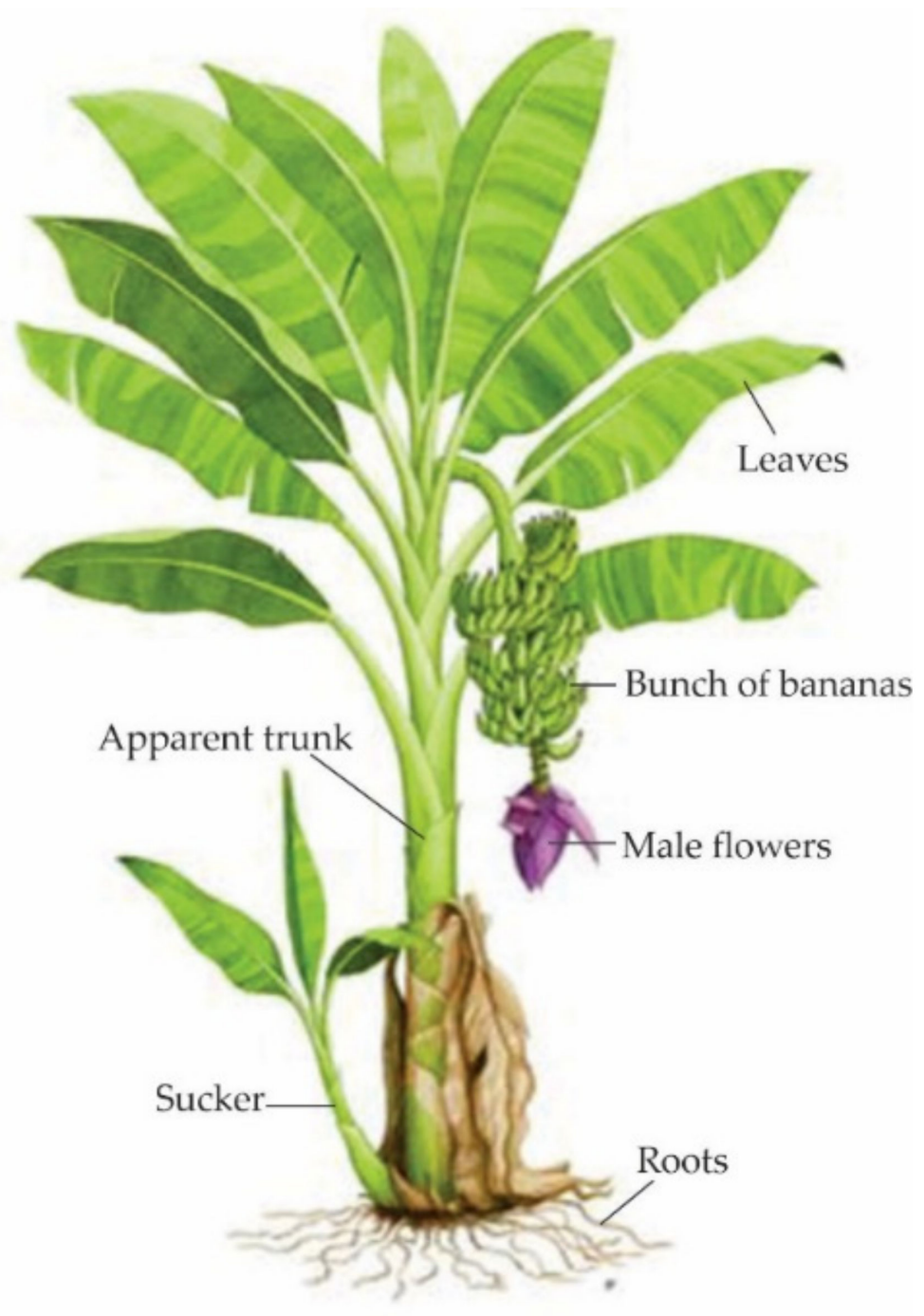

Figure 4. Parts of the banana plant. Adapted from [33].

The fruit contains various chemical components (Table 2), especially dietary fiber and sugars. During the early part of ripening, sucrose is the predominant sugar, but in the later stages, glucose and fructose predominate [44]. The conversion of starch to sucrose is catalyzed by sucrose phosphate synthase activity, while hydrolysis causes the conversion of starch to non-reducing sugars from sucrose [44]. Bananas are considered a good source of potassium and magnesium, essential components in nutrition and their functional roles involve structural, physiological and metabolic processes in the body [45]. Bananas can provide macro and micro minerals in the diet such as $\mathrm{P}, \mathrm{K}, \mathrm{Ca}, \mathrm{Mg}, \mathrm{Na}$, which together with the carotenoids in the plant, play an essential role in the functioning and nutritional value [46].

The peel and pulp are good sources of certain biogenic amines (catecholamines) produced by decarboxylation of amino acids or amination of aldehydes and ketones. Catecholamines include dopamine, serotonin, epinephrine and norepinephrine [47]. Serotonin is crucial for the correct functioning of the nervous system and control of blood pressure in humans. On the other hand, putrescine contributes to physiological processes such as flowering, fruit development and cell division. Putrescine is also used as a quality indicator in various foods [48]. In addition, bananas contain phenolic compounds that help prevent many human disorders such as cardiovascular diseases, obesity and diabetes [49]. 
Table 2. Chemical composition of Banana fruit.

\begin{tabular}{|c|c|c|c|}
\hline Compound & Content & Unit & References \\
\hline Carbohydrates & $22-88$ & g/100g DW & {$[43,50,51]$} \\
\hline Dietary fiber & $2-5$ & $\mathrm{~g} / 100 \mathrm{~g} \mathrm{DW}$ & {$[45,51,52]$} \\
\hline Protein & $1-2$ & g/100g DW & {$[43,53,54]$} \\
\hline Grease & $0.3-1.78$ & $\mathrm{~g} / 100 \mathrm{~g} \mathrm{DW}$ & {$[52,54,55]$} \\
\hline $\mathrm{AC}$ & 5 & $\mathrm{mg} / 100 \mathrm{~g}$ FW & {$[45,51,53]$} \\
\hline $\mathrm{P}$ & $350-485$ & $\mathrm{mg} / 100 \mathrm{~g} \mathrm{FW}$ & {$[45,46,51]$} \\
\hline $\mathrm{Mg}$ & $26-27$ & $\mathrm{mg} / 100 \mathrm{~g} \mathrm{FW}$ & {$[43,45,51]$} \\
\hline Vitamin C & 12.7 & $\mathrm{mg} / 100 \mathrm{~g} \mathrm{FW}$ & {$[43,51,53]$} \\
\hline Vitamin A & 12.4 & $\mathrm{mg} / 100 \mathrm{~g} * \mathrm{RAE}$ & {$[51,53]$} \\
\hline Folate & 20 & $\mu \mathrm{g} / 100 \mathrm{~g} \mathrm{FW}$ & {$[43,51,53]$} \\
\hline Cellulose & 5.47 & $\mathrm{~g} / 100 \mathrm{~g} \mathrm{DW}$ & {$[52,54]$} \\
\hline Hemicellulose & 18.83 & $\mathrm{~g} / 100 \mathrm{~g}$ DW & {$[44,54]$} \\
\hline Serotonin & 28 & $\mu \mathrm{g} / \mathrm{g} \mathrm{DW}$ & {$[4,46]$} \\
\hline Phenols & $1-8$ & g/100g DW & {$[46,50,54]$} \\
\hline Dopamine & 7.9-9.9 & $\mu \mathrm{g} / \mathrm{g} D W$ & {$[4,56]$} \\
\hline Putrescine & $25-50$ & $\mathrm{mg} / \mathrm{kg} \mathrm{DW}$ & {$[48,57]$} \\
\hline Norepinephrine & 1.9 & $\mu \mathrm{g} / \mathrm{g} \mathrm{DW}$ & [4] \\
\hline
\end{tabular}

Bananas, like most fruits, are acidic, with a pulp $\mathrm{pH}$ below 4.5. The primary organic acids in bananas are ascorbic, citric, malic and oxalic acid, industrially essential acids because they mainly act as antimicrobial agents, neutralizers and preservatives for food [51].

\section{Banana Processing}

Bananas are considered a household fruit and are mainly characterized by their fresh consumption. However, several finished products are derived from the processing and handling fresh bananas and their components [58]. Banana products include bananas in syrup and dried slices (without frying), frozen bananas, dried bananas, alcoholic beverages and ethanol from bananas, banana powder, jellies, jams, compotes, slices, juices, nectars, drinks, fried slices of banana and banana vinegar, among others [59].

Export bananas are subjected to an intensive quality control process to ensure that they reach the final destination in an optimal state of ripeness and free of stains, dirt and scars from abuse [60]. At the processing plants where the banana is selected and packaged, discarded fruits that have not reached an optimal state of maturity, the right size, have slight bumps or bruises, insect pickets and stains, generate the traditional banana rejection, a waste-loss of the banana processing together with the waste-loss of the postharvest process [61]. Bananas are classified into three categories according to the Food Codex: Extra Class, in which the bananas must be of superior quality and representative of the variety or commercial type to which they belong; Class I, in which the bananas must be of good quality and exhibit the characteristics of the variety; and Class II, which includes bananas which cannot be classified in the higher classes but satisfy the minimum requirements for fresh consumption [62].

The banana industry is characterized by producing waste-loss from roots, stems, leaves, or any other part of the plant (Figure 5) that is not used during the processing. However, they share the content of lignin, cellulose, pectin and hemicellulose [63]. 


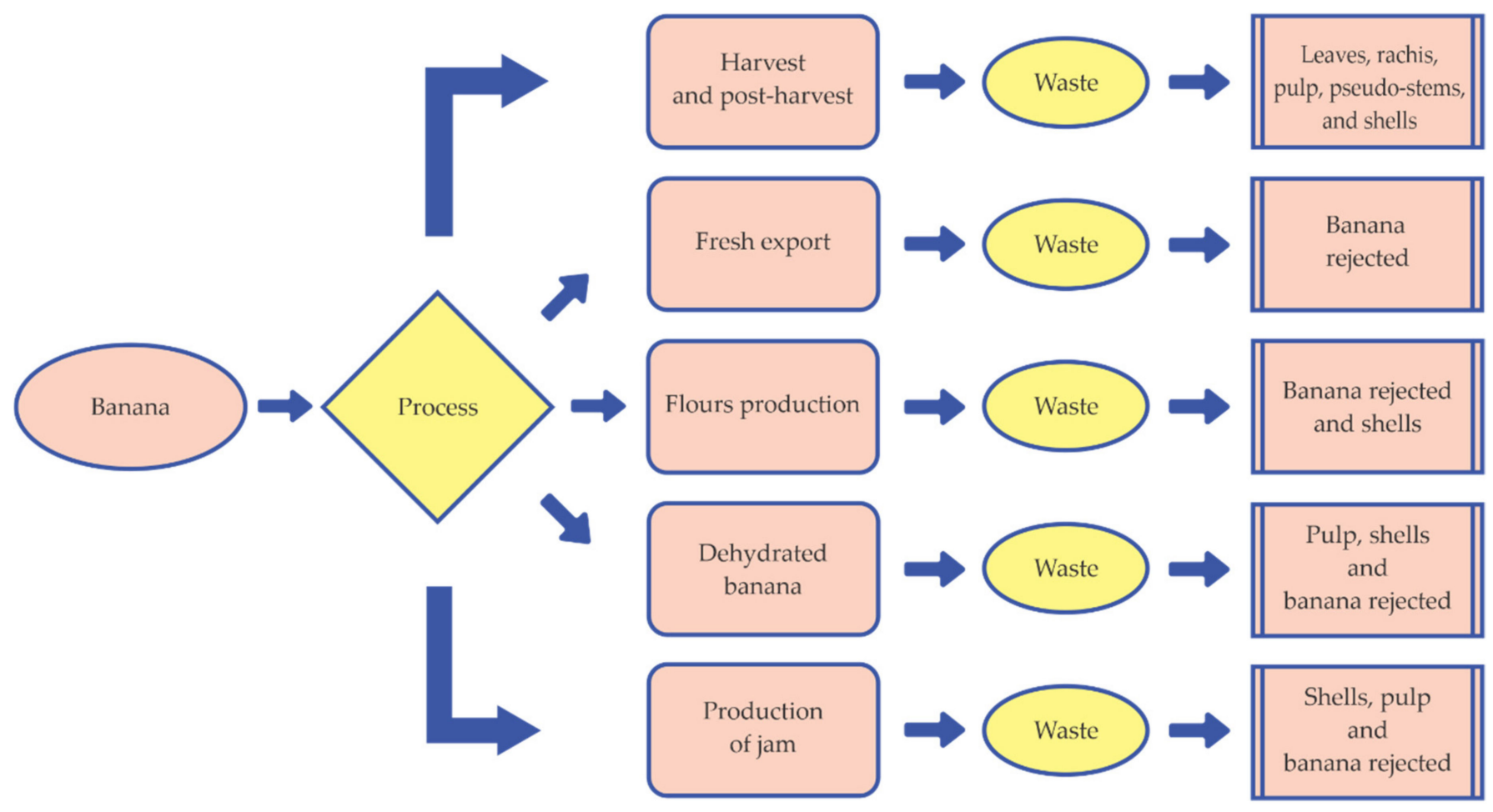

Figure 5. Scheme of production of waste-loss from the banana processing.

\subsection{Peel}

Banana peel is one of the essential waste-loss generated from processing. Bananas contain $60 \%$ pulp and $40 \%$ peel, $7.25 \mathrm{~kg}$ of peel produced from a banana box of $18.14 \mathrm{~kg}$ [64]. However, the shell contains carbon-rich organic compounds such as cellulose (7.6-9.6\%), hemicellulose (6.4-9.4\%), pectin (10-21\%), lignin (6-12\%), chlorophyll pigments and some other low molecular weight compounds (Table 3). If not treated properly, these wastes create an annoying odor due to the natural decomposition and produce gases that contribute to the greenhouse effect [65].

Table 3. Chemical composition of dry-based banana peel in solid state [66-68].

\begin{tabular}{cc}
\hline Components & $(\mathbf{m g} / \mathbf{1 0 0 g}$ Dry Peel) \\
\hline Starch & 0.78 \\
\hline Raw fiber & 11.95 \\
\hline Crude protein & 4.77 \\
\hline Calcium & 0.36 \\
\hline Phosphorus & 0.23 \\
\hline Lipids & 1.15 \\
\hline Zinc & 0.17 \\
\hline Ash & 1.71 \\
\hline
\end{tabular}

\subsection{Pseudostems}

Pseudostems are the banana stem that supplies nutrients from the soil to the fruits. It is structured by two elements, the nodes and internodes, which make up the floral stem and support the inflorescence in the inner part [69]. The outer part is formed by the sheaths of several bases of rolled leaves emerging from the knots of the corm and the floral stem, arranged in the form of a basal and helical rosette at $120^{\circ} \mathrm{C}$. The size varies between three and five meters high, and its diameter is between 40 and $60 \mathrm{~cm}$ [70]. The fiber extracted 
from the banana's dried petioles and the pseudostem is utilized in paper [71]. The chemical composition of the dry-based pseudostem is described in Table 4.

Table 4. Chemical composition of pseudostems from banana on a dry basis.

\begin{tabular}{cc}
\hline Components & $(\mathbf{m g} / \mathbf{1 0 0 g}$ Dry Peel) \\
\hline Ash & 28.3 \\
\hline Coal & 38.3 \\
\hline Hydrogen & 3.88 \\
\hline Sulfur & 0.58 \\
\hline Lignin & 5.2 \\
\hline Cellulose & 35.3 \\
\hline hemicellulose & 24.9 \\
\hline
\end{tabular}

\subsection{Pulp}

Banana pulp is a rich source of essential phytonutrients, including phenolic compounds and vitamins (B3, B6, B12, C and E). It also contains carotenoids, flavonoids, amine compounds and dietary fiber [72]. Dietary fibers are polymers of non-digestible carbohydrates that are classified based on their water solubility into two types, soluble fibers (pectin and some hemicellulose) and insoluble fibers (cellulose, lignin and resistant starch) [73]. The chemical composition for banana pulps is described in Table 5 .

Table 5. Chemical composition of banana pulp on a dry basis $[74,75]$.

\begin{tabular}{cc}
\hline Components & Composition (\% DW) \\
\hline Starch & 18.4 \\
\hline Protein & 3.1 \\
\hline Cellulose & 0.8 \\
\hline Fat & 0.62 \\
\hline Sugars & 2.1 \\
\hline Ash & 0.53 \\
\hline Phosphorus & 0.13 \\
\hline Soluble carbohydrates & 67.2 \\
\hline Ethereal extract & 0.9
\end{tabular}

DW: Dry weight.

\section{Use of Banana Waste-Loss}

In recent decades, the world population increased up to 7 billion, generating around 683 million tons of agri-food waste, $34 \%$ related to waste-loss of food produced worldwide [76].

The use of this waste-loss has become a topic of great interest, leading to the transition and implementation of a circular economy model as a regenerative economic model [77]. The objective is to close the life cycle of the products through an increase and optimization of use. This objective is also seen in overall favorable balances for the environment and the economy [78].

Sustainable development of the circular economy concept is only possible if technologies are adopted to recover waste-losses. The recovery of food waste-loss opens up new economic growth horizons, allowing the opportunity to transform raw material into a circular loop [79]. The banana industry produces a high amount of lignocellulosic waste that can be used in different recovery processes such as biofuels, wastewater treatment, bioplastics, organic fertilizer and nanotechnology applications. The variety of bananas most used in waste-loss is the Cavendish and Gros Michel varieties, due to their high availability in 
different countries such as India, Philippines and Ecuador, detailed in Section 2. In addition, it should be noted that the most used residues are the peel and pseudostem from bananas due to their high content of cellulose, hemicellulose and fiber. Musa paradisiaca spp. is one of the most demanded varieties in the harvesting industry. Thanks to the composition of its residues, it can be used in all the applications mentioned above. Banana Cavendish is widely used in biofuels because sugars represent the species' main component of soluble solids. By subjecting them to cellulolytic organisms, a greater quantity of fermented sugars is necessary for biofuel production. Furthermore, the varieties Williams, Musa balbisiana and Musa accuminata have good potential for use in wastewater treatment, bioplastics and nanotechnology applications thanks to their physicochemical properties, such as its lignocellulosic content, its density and its ability to adapt to extreme conditions of climate, soil and water. The chemical composition and physical structure of the waste-loss of banana studied in this paper can be observed in the different tables in Section 3.

\subsection{Biofuel Production}

Due to the rapid development of the automotive industry and environmental pollution problems, the growing demand for petroleum-derived fuel has inspired efforts to explore alternative fuels [73].

The lignocellulosic biomass from the shell, pseudostems and rachis of banana represents a source of promising raw material for ethanol production due to its abundance and high availability. Agri-food waste can be used locally, and does not trigger competition between fuel and food [80]. The production of bioethanol from lignocellulosic biomass (Figure 6) comprises four main stages: the pretreatment of the raw material, the enzymatic saccharification, the fermentation and the recovery of the product- the final crucial step for the process to be economically viable on a commercial scale due to high energy consumption [81].

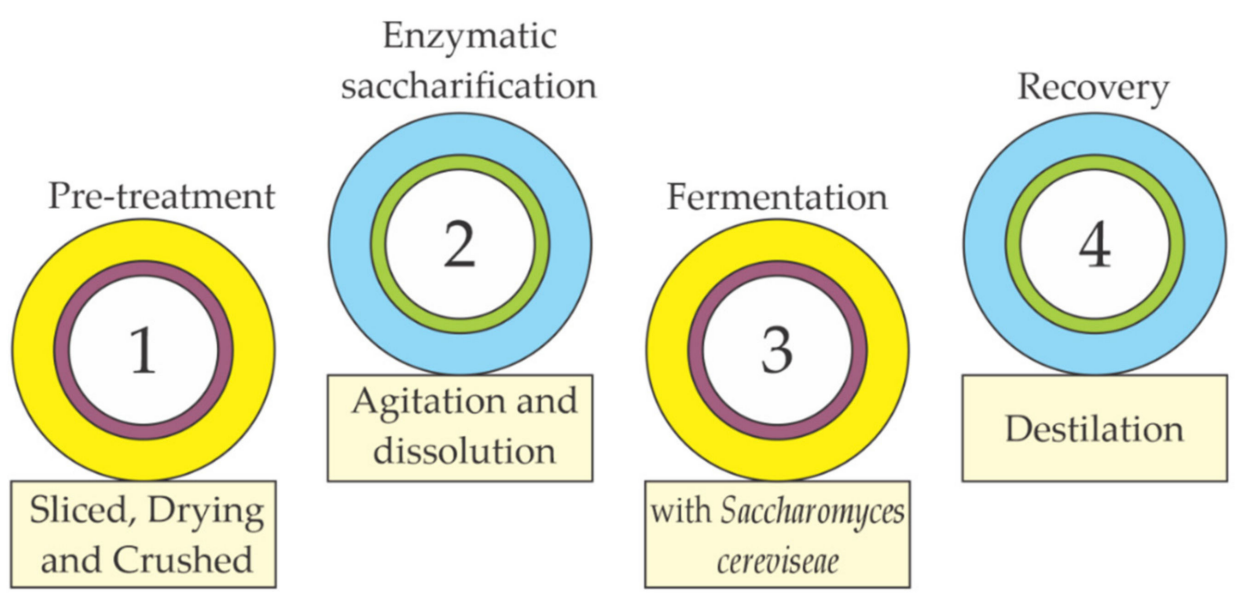

Figure 6. Stages of the bioethanol production process. Adapted from [81].

The banana rachis is chopped to reduce their size to $1 \mathrm{~cm}$ in width in the pretreatment, dried and later crushed for their correct use in the other processes [82]. The enzymatic treatment can be carried out in two-liter bioreactors at a concentration of $60 \%$ (dry weight) of the shell. The waste-loss are dissolved and stirred in purified water, and during this stage, it is vital to measure the $\mathrm{pH}$, the sugar content and the dissolved oxygen [83]. Fermentation is the anaerobic degradation of organic substances using catalysts presented by some microscopic organisms, such as yeasts. During this process, glucose is transformed into ethanol and carbon dioxide thanks to fermentative processes of yeasts such as Saccharomyces cerevisiae [84]. Finally, with the distillation of the alcohol, the aim is to remove the final product due to the difference in boiling point, and as much water is separated to obtain alcoholic beverages with the highest concentration possible (around $40 \% v / v)$ [85]. 
Finally, with the distillation of the alcohol, the aim is to remove the final product due to the difference in boiling point, and as much water is separated to obtain alcoholic beverages with the highest concentration possible (around 40\% v/v) [85].

On the other hand, the fermentation of banana waste-loss can produce biogas. The production occurs through anaerobic fermentation, one of the most frequent biological processes used to decompose organic materials [86]. Biogas comprises $55-70 \%$ methane, $30-45 \%$ carbon dioxide and other minor compounds such as water, hydrogen sulfide, ammonia, nitrogen and traces of volatile organic compounds such as siloxanes and terpenes [87]. Biogas quality is highly dependent on the digested substrate(s) and the process parameters. Furthermore, calorific value is conditioned by the concentration of methane in the mixture. For this reason, carbon dioxide and the other impurities must be removed to obtain high purity bio-methane with characteristics superior to natural gas, but with the advantage that the machinery will not be affected by corrosion [88].

Another biofuel alternative that is produced from the use of banana waste-loss is hydrogen. Biomass gasification is a promising technology for converting different raw materials for various energy purposes. This complex thermochemical process converts lignocellulosic materials into a more valuable gas known as synthesis gas through a series of reactions at high temperatures, with the presence of gasifying agents such as air, steam, oxygen or mixtures [89]. The production of hydrogen from ethanol on $\mathrm{Cu} / \mathrm{Nb}_{2} \mathrm{O}_{5}$ catalysts promoted with $\mathrm{Pd}$ and $\mathrm{Ru}$ has received particular attention in research, since it shows promising selectivity for hydrogen selectivity and ethanol conversion in reform reactions using low-cost materials [90]. Hydrogen offers many sustainable end-uses for both small and large scale. Hydrogen end-use options range from highly efficient fuel cells to internal combustion engines. Furthermore, hydrogen can be used as an energy carrier and storage medium in smart grids and other novel applications [91].

Biodiesel is produced from the transesterification of a wide variety of oils and fats (triglycerides), including recycled oils and low-molecular-weight alcohols (mainly methanol and ethanol) [92]. However, biodiesel production from banana waste-loss has been reported mainly at the laboratory level (Table 6). Biodiesel production from the transesterification of triglycerides with short-chain alcohols with the presence of a catalyst consists of three consecutive reversible reactions, where triglycerides are converted to diglycerides, monoglycerides and finally to glycerol. In addition, an ester molecule (biodiesel) formation occurs [93]. Due to the reversibility of the reaction, an excess of alcohol is necessary to improve biodiesel production [92]. Catalysts derived from banana peduncle, peel and pseudostems are some of the solid catalysts based on biomass waste-loss that have been used successfully in recent years (Table 6) [94].

Table 6. Biofuel production studies using banana waste-loss.

\begin{tabular}{|c|c|c|c|c|c|}
\hline Waste-Loss & Biofuel & Study Scale & Objective & Conclusions & References \\
\hline \multirow{2}{*}{$\begin{array}{l}\text { Industrial } \\
\text { waste-loss, peel } \\
\text { and rachis of } \\
\text { Cavendish banana }\end{array}$} & \multirow[t]{2}{*}{ Bioethanol } & \multirow[t]{2}{*}{ Laboratory } & $\begin{array}{l}\text { Three experiments were carried out on } 60 \\
\text { \% ground banana peel. Enzymatic } \\
\text { hydrolysis was carried out with conidia of } \\
\text { the Trichoderma viride fungus and its } \\
\text { subsequent alcoholic fermentation was } \\
\text { with commercial dry active yeast } \\
\text { Saccharomyces cerevisiae. }\end{array}$ & $\begin{array}{l}\text { The results show that } \\
\text { bioethanol can be obtained } \\
\text { from the lignocellulosic } \\
\text { waste-loss of the mature banana } \\
\text { shell with a yield of } 7 \%(v / v) .\end{array}$ & [83] \\
\hline & & & $\begin{array}{l}\text { Different mixtures of water and banana } \\
\text { peels left to ferment for several days. The } \\
\text { rachis was subjected to an alkaline } \\
\text { hydrolysis process with } \mathrm{NaOH} \text { to } \\
\text { obtain ethanol. }\end{array}$ & $\begin{array}{c}\text { Ethanol obtained were an } \\
\text { average pH of } 4.16,3.75^{\circ} \text { Brix, } \\
\text { with a concentration of } 29 \\
\text { alcoholic degrees, with a } \\
\text { distillate flow rate of } 8.3 \mathrm{~mL} / \mathrm{s} \text {. }\end{array}$ & [84] \\
\hline
\end{tabular}


Table 6. Cont.

\begin{tabular}{|c|c|c|c|c|c|}
\hline Waste-Loss & Biofuel & Study Scale & Objective & Conclusions & References \\
\hline \multirow{2}{*}{$\begin{array}{l}\text { Musa acuminata } \\
\text { Pseudo stems, } \\
\text { rachis and peel }\end{array}$} & \multirow[b]{2}{*}{ Biogas } & Laboratory & $\begin{array}{l}\text { In this study, the division into four stages } \\
\text { of anaerobic digestion was carried out, in } \\
\text { which anaerobic bioreactor and ripe } \\
\text { banana peels were used. }\end{array}$ & $\begin{array}{c}\text { After } 8 \mathrm{~h}, 1 \mathrm{~L} \text { of gas was } \\
\text { obtained in the sampling } \\
\text { system. A CO } 299.97 \% \\
\text { concentration was obtained. }\end{array}$ & [86] \\
\hline & & Pilot plant & $\begin{array}{l}\text { The biomass fraction was subjected to } \\
\text { anaerobic digestion. Then a steam } \\
\text { explosion pretreatment was implemented } \\
\text { to increase the methane yield in the } \\
\text { co-management of urban solid waste } \\
\text { (pseudostem and rachis). }\end{array}$ & $\begin{array}{l}\text { A yield of } 363.29 \mathrm{~L} \text { of } \mathrm{CH}_{4} / \mathrm{kg} \\
\text { of solid waste was obtained, } \\
\text { equivalent to } 56.32 \mathrm{kWh} / \mathrm{tbh} \text {. } \\
\text { The C/N ratio was adjusted to } \\
\text { the } 20-30 \text { range. }\end{array}$ & [87] \\
\hline \multirow{2}{*}{$\begin{array}{l}\text { Banana peel and } \\
\text { stalk of } M u s a \text { spp. }\end{array}$} & \multirow{2}{*}{ Biodiesel } & \multirow{2}{*}{ Laboratory } & $\begin{array}{l}\text { The feasibility of using the ash derived } \\
\text { from the peduncle of Musa spp as a highly } \\
\text { effective renewable heterogeneous catalyst } \\
\text { for the transesterification of underutilized } \\
\text { non-edible Ceiba pentandra oil (CPO) } \\
\text { was investigated. }\end{array}$ & $\begin{array}{l}\text { Optimal process conditions } \\
\text { were a catalyst concentration of } \\
1.978 \% \text { by weight, a reaction } \\
\text { time of } 60 \text { min, with an } \\
\text { expected yield of } 99.36 \% \text {, which } \\
\text { was experimentally evaluated } \\
\text { as } 98.69 \pm 0.18 \% \text {. }\end{array}$ & [95] \\
\hline & & & $\begin{array}{l}\text { Cryptococcus sp. was used to produce oil } \\
\text { with banana peel as raw material. } \\
\text { Pretreatment of the banana peel with } 1 \% \\
\text { sulfuric acid produced up to } 4.5 \mathrm{~g} \text { of } \\
\text { glucose ( } 11.2 \% \text { yield) and } 18.1 \mathrm{~g} \text { of } \\
\text { fructose }(45.2 \% \text { yield). }\end{array}$ & $\begin{array}{l}\text { When Cryptococcus sp. was } \\
\text { grown on the pretreated banana } \\
\text { peel, its accumulated lipids up } \\
\text { to } 34.0 \% \text {. The lipid had a high } \\
\text { degree of monosaturated, } \\
\text { which gave the resulting } \\
\text { biodiesel a better quality. }\end{array}$ & [96] \\
\hline \multirow[b]{2}{*}{$\begin{array}{l}\text { Peel and rachis } \\
\text { from } M u s a \\
\text { paradisiaca }\end{array}$} & \multirow[b]{2}{*}{ Hydrogen } & \multirow[b]{2}{*}{ Laboratory } & $\begin{array}{l}\text { This study analyzes banana peels' } \\
\text { pretreatment effect in the } \\
\text { photo-fermentative hydrogen production } \\
\text { using brewery wastewater (BWW) in a } \\
\text { discontinuous bioreactor. }\end{array}$ & $\begin{array}{l}\text { The maximum hydrogen } \\
\text { production yield ( } 408.33 \mathrm{~mL} \\
\mathrm{H}_{2} / \mathrm{L} \text { of wastewater) was } \\
\text { achieved from the substrate, } \\
\text { composed of } 50 \% \text { body weight } \\
\text { pretreated with } 1 \mathrm{~g} / \mathrm{L} \text { of banana } \\
\text { peels for two hours and } 50 \% \\
\text { medium standard. }\end{array}$ & [97] \\
\hline & & & $\begin{array}{l}\text { The drying process was carried out in an } \\
\text { oven at } 65^{\circ} \mathrm{C} \text { until a constant weight was } \\
\text { achieved. The biomass pyrolysis was } \\
\text { carried out in an electric oven. The system's } \\
\text { temperature was between } 250^{\circ} \mathrm{C}, 275^{\circ} \mathrm{C} \\
\text { and } 300^{\circ} \mathrm{C} \text { for } 30 \mathrm{~min} \text { in each experiment. }\end{array}$ & $\begin{array}{l}\text { The results show that the } \\
\text { pyrolysis process does not } \\
\text { depend on the size of the } \\
\text { particles or the content of } \\
\text { reducing sugar. The production } \\
\text { at } 250^{\circ} \mathrm{C} \text { was about } 1 \mathrm{mg} \text { of } \\
\text { hydrogen. At } 275^{\circ} \mathrm{C} \text {, } \\
\text { production increased and then } \\
\text { fell to } 300^{\circ} \mathrm{C} \text {. }\end{array}$ & [98] \\
\hline \multirow{2}{*}{$\begin{array}{l}\text { Banana peel } \\
\text { cavendish }\end{array}$} & \multirow{2}{*}{ Biochar } & \multirow{2}{*}{ Laboratory } & $\begin{array}{l}\text { This study focused on the yield of biochar } \\
\text { and its production through the response } \\
\text { surface methodology using a central } \\
\text { compound design (CCD) in the pyrolysis } \\
\text { of the batch reactor. }\end{array}$ & $\begin{array}{l}\text { The biochar obtained by slow } \\
\text { pyrolysis at } 356.1^{\circ} \mathrm{C} \text { and heating } \\
\text { rate of } 14.7^{\circ} \mathrm{C} / \mathrm{min} \text { had a } \\
\text { bio-carbon yield and an } \mathrm{O} / \mathrm{C} \\
\text { ratio of } 58.8 \% 0.289 \text {, respectively. }\end{array}$ & [99] \\
\hline & & & $\begin{array}{l}\text { Five tests were carried out: Free (Control), } \\
1 \% \text { banana peel (P1), } 2 \% \text { banana peel (P2), } \\
1 \% \text { biochar (B1) and } 2 \% \text { biochar (B2) to } \\
\text { evaluate the greenhouse gas emissions } \\
\text { into the atmosphere. }\end{array}$ & $\begin{array}{l}\text { Carbon dioxide emissions for } \\
\text { treatments B1 and B2 decreased } \\
\text { by } 20 \% \text { and } 24 \% \text { compared to } \\
\text { banana peel, respectively. }\end{array}$ & [100] \\
\hline
\end{tabular}

\subsection{Wastewater Treatment}

According to the World Wildlife Organization (WWF), more than 1100 million people do not have access to drinking water worldwide because the growing population demands safe drinking water insurance [101].

Several organic and inorganic products are considered toxic pollutants frequently released into the environment, mainly in surface waters [102]. The industrial and agricultural sectors promote chemical contamination of water due to the various metals, colorants, pesticides, drugs and other compounds that are often used [103]. 
There is a progressive increase in heavy metals such as chromium, mercury, nickel, cadmium and copper in drinking and wastewater samples that account for the increasing contamination. In the case of hexavalent chromium, it behaves as a toxic element. Chromium is considered harmful for red blood cells, liver, spleen, kidney, soft tissues and bones, affecting the digestive, respiratory and urinary systems [104]. Chromium is a potentially toxic and carcinogenic metal originating from natural processes and anthropogenic activities such as the iron steel, electroplating and leather industries [105]. For removing heavy metals from the water using biomass, techniques such as adsorption, membrane filtration, or chemical precipitations can be used, which are explained schematically in Figure 7 [106].

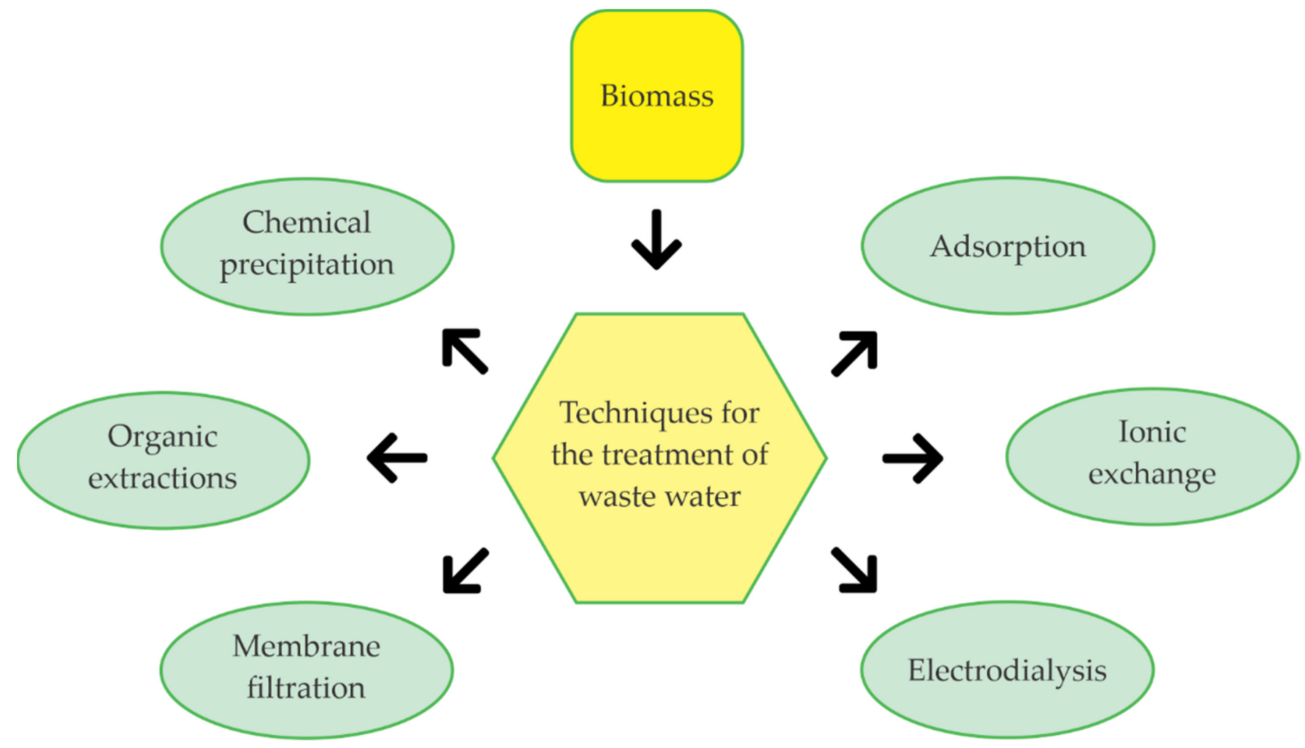

Figure 7. Techniques for the removal of heavy metals present in the water through banana biomass.

Banana rachis has been used in adsorption and chemical precipitation methods to remove chromium from wastewater, obtaining a removal efficiency of $99.8 \%$ at pH 6.7 [107]. Banana peel has been used as a low-cost adsorption method for oil removal from oil well water, resulting in up to $96 \%$ [108]. Electrodialysis (ED) is a membrane technology with many applications, such as water desalination, wastewater treatment and salt production. Additionally, utilizing the bacterial nanocellulose obtained from the shell of Musa spp, filters composed of catalytic membranes can be elaborated [109,110]. Banana peel has been proven to be an excellent low-cost adsorbent, as it is also used in the removal of metals such as nickel and the treatment of synthetic wastewater. Employing electrokinetic remediation, the banana and dioctyl sodium sulfosuccinate shell showed nickel removal percentages of $74.8 \%$. In addition, it is possible to obtain coagulants using banana peel extraction methods to remove turbidity from synthetic wastewater with a removal efficiency of $88 \%$ [111,112].

On the other hand, lead, a reasonably malleable corrosion-resistant metal, because it melts quickly, has several uses, and is expected mainly in paints and toxic fumes from industries such as metallurgy, mining and construction industries [113]. It has been shown that through the use of banana peel, removal efficiencies of up to $98 \%$ can be achieved with initial concentrations of $100 \mathrm{mg} / \mathrm{L}, \mathrm{pH} 5.0$, the adsorbent dosage of $0.55 \mathrm{~g}$ and particle size of $75 \mu \mathrm{m}$ [114].

Another pollutant in wastewater is cadmium, formed by burning metals in the air or pyrolysis of carbonates and nitrates. Cadmium toxicity can affect bones, the respiratory system, kidneys, reproduction and is potentially carcinogenic [115]. Sometimes, the banana marrow comes from the inner part of the pseudostem and is used for livestock, although it is usually discarded without any use [116]. The marrow as a coagulant generated a 
98.5\% removal of cadmium under acidic conditions due to many functional groups, such as hydroxyl, carboxylic and ether groups [117].

Several studies have been reported on the treatment of wastewater using banana waste-loss (Table 7). Cellulose and hemicellulose from banana pseudostems have created filters to eliminate organic pollutants [118]. In the same way, the rachis and shells of Musa paradisiaca have been treated with chemical compounds, such as $\mathrm{HCl}$ and $\mathrm{NaOH}$, to obtain activated carbon useful in the chromium removal from wastewater produced in the textile industry [119].

Table 7. Studies on wastewater treatment using banana waste-loss.

\begin{tabular}{|c|c|c|c|c|c|}
\hline Waste & Technique & Scale of Study & Study & Conclusions & References \\
\hline \multirow{2}{*}{$\begin{array}{l}\text { Pseudo stems } \\
\text { and shell of } \\
\text { Musa } A A B\end{array}$} & \multirow[b]{2}{*}{ Biofilters } & \multirow{2}{*}{ Laboratory } & $\begin{array}{l}\text { The } \mathrm{Cr}(\mathrm{VI}) \text { was dispersed in } 10 \mathrm{~mL} \text { of acetone. } \\
\text { The banana peels were washed with distilled } \\
\text { water and subsequently dried at } 120{ }^{\circ} \mathrm{C} \text { for } \\
12 \mathrm{~h} \text {. Adsorption dynamics of the samples } \\
\text { were analyzed utilizing batch reactors. }\end{array}$ & $\begin{array}{l}\text { The bananas in the mixture } \\
\text { removed almost all the } \mathrm{Cr}(\mathrm{VI}) \text { from } \\
\text { the typical synthetic wastewater } \\
\text { present in the tannery effluent } \\
\text { (removal percentage of } 93 \% \text { ). }\end{array}$ & [104] \\
\hline & & & $\begin{array}{l}\text { Cellulose was extracted from the } \\
\text { pseudostems (39.12\% cellulose and } 72.71 \% \\
\text { holo-cellulose) to elaborate the biofilter. } \\
\text { Efficiency was analyzed in terms of } \\
\text { decreasing biological oxygen demand, } \\
\text { chemical oxygen and suspended solids. }\end{array}$ & $\begin{array}{l}\text { The biofilter was able to remove } \\
\text { organic pollutants with efficiencies } \\
\text { between } 70.4 \text { and } 84.2 \% \text {. }\end{array}$ & [118] \\
\hline \multirow{2}{*}{$\begin{array}{l}\text { Rachis and } \\
\text { shells from } \\
\text { Musa } \\
\text { paradisiaca }\end{array}$} & \multirow{2}{*}{$\begin{array}{l}\text { Activated } \\
\text { carbon }\end{array}$} & \multirow[b]{2}{*}{ Laboratory } & $\begin{array}{l}\text { The banana rachis was cut, dried and then } \\
\text { burned to produce charcoal. Charcoal }(3 \mathrm{~g}) \text { was } \\
\text { mixed with } 75 \mathrm{~mL} \text { of chromium-containing } \\
\text { wastewater and then the chromium content in } \\
\text { the filtrate was measured. }\end{array}$ & $\begin{array}{l}\text { The removal efficiency was } 99.8 \% \\
\text { at pH } 6.7 \text {. The reduction } \\
\text { efficiencies of biological, } \\
\text { biochemical oxygen, chemical } \\
\text { oxygen demand and chloride were } \\
97 \%, 93 \% \text { and } 60 \% \text {, respectively. }\end{array}$ & [107] \\
\hline & & & $\begin{array}{l}\text { Shell was dried under atmospheric } \\
\text { conditions for two days, then dried in an } \\
\text { oven at } 80^{\circ} \mathrm{C} \text { for } 18 \mathrm{~h} \text {. } \mathrm{HCl} \text { and } \mathrm{NaOH} \text { were } \\
\text { mixed. They were then smoothed and } \\
\text { classified according to vibrating screens with } \\
\text { the largest mesh size of } 300 \mu \mathrm{m} \text {. }\end{array}$ & $\begin{array}{l}\text { It was possible to reduce copper } \\
\text { and chromium ion content by } \\
55.5 \% \text { and } 61 \% \text {. For dyes in textile } \\
\text { waste, the average absorption } \\
\text { capacity of the dye ion was } \\
12.21 \% \text { during } 120 \mathrm{~min} .\end{array}$ & [119] \\
\hline $\begin{array}{l}\text { Musa } \\
\text { Acuminata } \\
\text { shells }\end{array}$ & Coagulant & Laboratory & $\begin{array}{c}\text { The shells were washed with distilled water } \\
\text { and cut to } 0.6 \mathrm{~cm} \text {. They were then oven-dried } \\
\text { for } 48 \mathrm{~h} \text { at } 60^{\circ} \mathrm{C} \text {. Then, } 0.5 \mathrm{~g} \text { of the raw } \\
\text { material was soaked in } 100 \mathrm{~mL} \text { of distilled } \\
\text { water at room temperature and stirred at } 120 \\
\text { rpm for one hour. }\end{array}$ & $\begin{array}{l}\text { It could be concluded that the } \\
\text { coagulant was highly effective in } \\
\text { removing turbidity from synthetic } \\
\text { wastewater with a removal } \\
\text { efficiency of } 88 \% \text { under conditions } \\
\text { of pH } 1.0 \text { and a dose of } 100 \mathrm{mg} / \mathrm{L} \text {. }\end{array}$ & [112] \\
\hline \multirow{3}{*}{$\begin{array}{l}\text { Musa spp. } \\
\text { shells }\end{array}$} & \multirow[t]{2}{*}{ Biosorbent } & \multirow[t]{2}{*}{ Laboratory } & $\begin{array}{c}\text { Electrokinetic remediation was used for } \\
\text { nickel removal. Different electrodes with } \\
\text { different purge solutions (pH } 3.5 \text { and } 7.0 \text { ) and } \\
\text { anionic surfactant (sodium dioctyl } \\
\text { sulfosuccinate) were used. The shells were } \\
\text { ground, washed and then dried in an oven } \\
\text { for two days. }\end{array}$ & $\begin{array}{l}\text { The removal efficiency was } 74.8 \% \text {. } \\
\text { Biological remedies are considered } \\
\text { an effective adsorbent material to } \\
\text { prevent reverse osmosis flow, } \\
\text { which provides a new idea for } \\
\text { applying these products as an } \\
\text { adsorption medium. }\end{array}$ & [111] \\
\hline & & & $\begin{array}{l}\text { The shell was washed with distilled water and } \\
\text { ground to a particle size of } 2 \mathrm{~mm} \text {. Then, } \\
\text { grounding and washing with n-hexane; } \\
\text { subsequently, drying in an oven at } 100{ }^{\circ} \mathrm{C} \text { for } 12 \mathrm{~h} \text {. }\end{array}$ & $\begin{array}{l}\text { The banana peel was an excellent } \\
\text { absorbent for oil removal from } \\
\text { wastewater with greater than } 96 \% \\
\text { removal efficiency. }\end{array}$ & [108] \\
\hline & $\begin{array}{l}\text { Ceramic } \\
\text { mem- } \\
\text { brane }\end{array}$ & $\begin{array}{l}\text { Industrial } \\
\text { plant }\end{array}$ & $\begin{array}{c}\text { The shell was washed with distilled water } \\
\text { and ground. Clay was mixed in a mold } \\
\text { subjected to } 88 \mathrm{MPa} \text {. After milling, the raw } \\
\text { materials were dried at } 110^{\circ} \mathrm{C} \text { for four hours } \\
\text { and sieved at } 150 \mu \mathrm{m} \text {. }\end{array}$ & $\begin{array}{l}\text { Filtration from the tannery } \\
\text { revealed the removal of } \\
\text { contaminants. Turbidity, dye } \\
\text { content, suspended solids and } \\
\text { biological and chemical oxygen } \\
\text { demand were also reduced. }\end{array}$ & [120] \\
\hline $\begin{array}{c}\text { Musa } \\
\text { Sapientun } \\
\text { Pseudo stem }\end{array}$ & Biosorption & Laboratory & $\begin{array}{l}\text { The pseudostems were dried under sunlight } \\
\text { before drying in an oven for } 24 \mathrm{~h} \text { at } 105^{\circ} \mathrm{C} \text {. } \\
\text { All the experiments were carried out with the } \\
\text { batch method, varying the } \mathrm{pH}(2.0-10.0) \text {, } \\
\text { amount of biosorbent }(0.10,0.50,1,1.5,2,2 \mathrm{~g}) \\
\text { and contact time }(15-1440 \mathrm{~min}) .\end{array}$ & $\begin{array}{l}\text { Removals for oxygen demand of } \\
88 \% \text {, ammonia nitrogen of } 84 \% \text {, } \\
\text { suspended solids of } 83 \% \text {, } \\
\text { turbidity of } 75 \% \text {, the color of } 67 \% \\
\text { and oil and fat of } 68 \% \text { were } \\
\text { achieved. Maximum elimination } \\
\text { was achieved in two hours. }\end{array}$ & [121] \\
\hline
\end{tabular}




\subsection{Bioplastics}

Polymers can be natural, synthetic or semi-synthetic (Figure 8). Naturals include proteins, enzymes and polysaccharides, while synthetic plastics are thermoplastics, moldable with heating, or thermosets, which are not moldable under heating [122].

Bioplastics are also produced using other polysaccharides such as polyhydroxyalkanoates, collagen and lipids from vegetable oils. In this sense, food waste-loss as an initial raw material is a good option for elaborating biodegradable materials [123]. Starch is a natural polymer of glucose. It is considered a mixture of two polysaccharides: amylose and amylopectin. Starch constitutes the reserve of plant nutrients, and behind cellulose, it is the most abundant carbohydrate in nature [124]. Starch is not plastic, but it can become plastic through polymer technology or fermentation using various techniques such as casting, mixing, extrusion, or injection molding. Commercially, $50 \%$ of bioplastics are prepared from different starches [125].

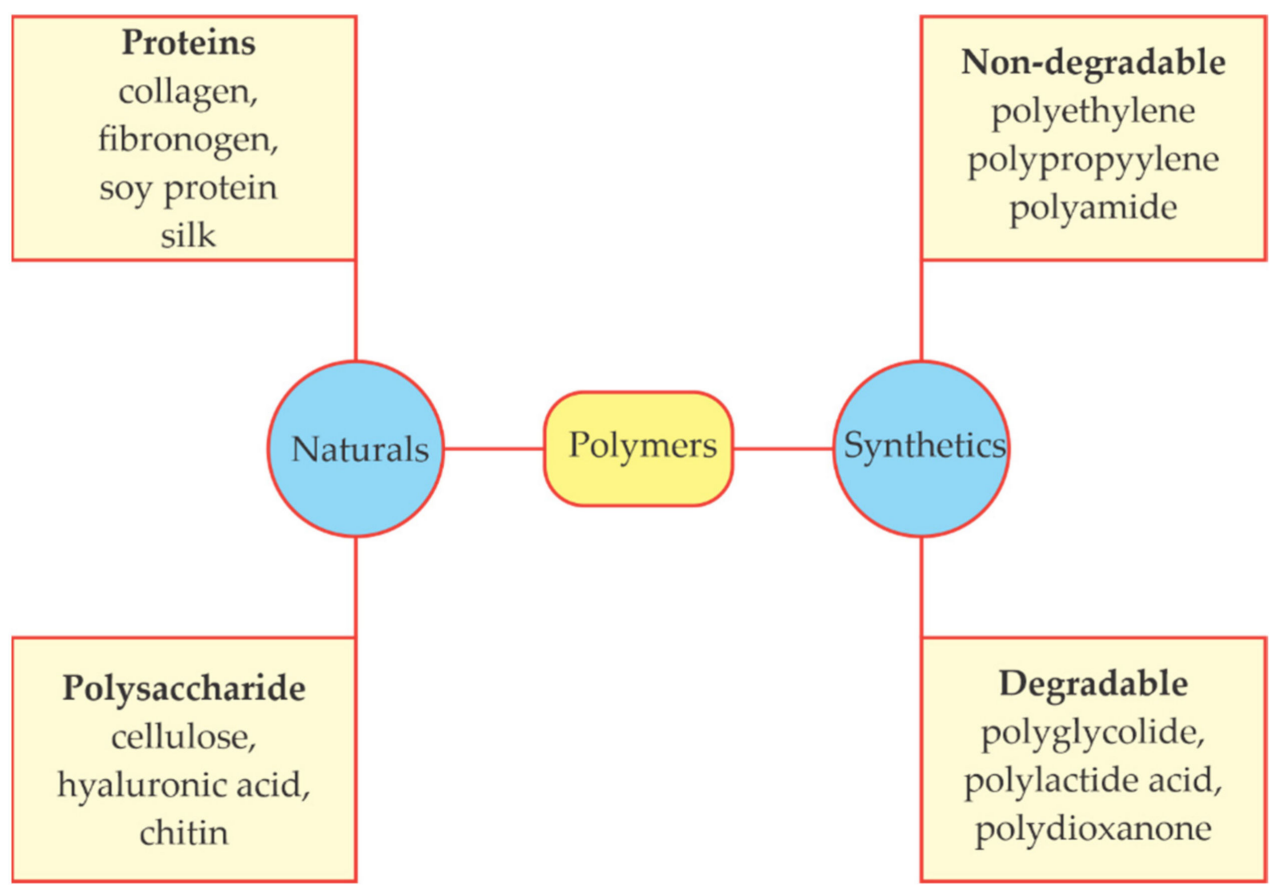

Figure 8. Examples of biodegradable and non-biodegradable natural and synthetic polymers. Adapted from [126].

The peels must be properly washed, cut and then heated with water to produce bioplastics from banana starch. Then they must be crushed and mixed with compounds such as acetic acid, glycerol, or sodium hydroxide [127]. The mixture is subjected to heating to $220^{\circ} \mathrm{C}$ with constant stirring, and is allowed to dry at room temperature for one day, followed by heating again in an oven at $85^{\circ} \mathrm{C}$ for two hours [128]. Compounds such as glycerol, sodium hydroxide and hydrochloric acid are essential in the bioplastic manufacturing process as they improve the plasticizing properties of the final product [129].

Polyhydroxybutyrate (PHB) is a biodegradable thermoplastic synthesized by submerged fermentation from renewable raw materials. It is a polyester composed of highly crystalline, rigid and brittle linear elastomers with chemical resistance to hydrolysis [130]. PHB has a methyl functional group and an ester linking group that provides the characteristics mentioned above [131]. More than 20 bacterial species include Bacillus megaterium, Methylobacterium rhodesianum, Alcaligenes eutrophus, Methylorubrum extorquens, Pseudomonas putida, Sphaerotilus natans and Escherichia coli, among others, are known as producers of PHB [132]. Through sequential steam pretreatment, enzymatic hydrolysates can be produced from the banana pseudostem, reducing PHB production costs and improving the commercialization [133]. Due to the biodegradability, biocompatibility, availability and 
physical properties comparable to petroleum-based thermoplastics, PHB is a potential substitute in the biomedical and packaging fields [134].

On the other hand, film food packaging avoids the loss of water, which causes a modification in texture and rigidity. In addition, food-packaging delays chemical changes such as color, aroma and nutritional value, since they act as a barrier against gases or volatile loss compounds that influences chemical and microbiological stability and avoid food decay and loss [135]. Banana leaves are used to make packaging (Table 8) due to their availability and ease of processability. Furthermore, leaves are large-size materials that have a degradation time of approximately 28 days after use. In addition, leaves can be stored for six months under proper conditions [136]. Biofilms made from starch share the characteristics of petroleum derivatives, while possessing advantages such as biodegradability and low toxicity [137].

Table 8. Manufacture of bioplastics from banana waste-loss.

\begin{tabular}{|c|c|c|c|c|c|}
\hline Residue & Biopolymer & Product & Study & Conclusions & References \\
\hline $\begin{array}{l}\text { Banana } \\
\text { leaves }\end{array}$ & $\begin{array}{l}\text { Musa spp. } \\
\text { fiber sheets }\end{array}$ & $\begin{array}{c}\text { Biodegradable } \\
\text { packaging }\end{array}$ & $\begin{array}{l}\text { Study on an industrial scale. Metal molds } \\
\text { were elaborated to do the press and ironing } \\
\text { of the sheets of banana and rice to give it } \\
\text { shape and firmness. Rice powder was mixed } \\
\text { with water and heated to a paste that was } \\
\text { added to the banana sheets. }\end{array}$ & $\begin{array}{l}\text { Two types of packaging were } \\
\text { obtained (rectangular and } \\
\text { cylindrical shape), capable of } \\
\text { biodegrading } 90 \% \text { in approximately } \\
\text { six months. }\end{array}$ & [136] \\
\hline $\begin{array}{l}\text { Pseudo } \\
\text { stems }\end{array}$ & $\begin{array}{c}\text { Musa } \\
\text { Acuminata } \\
\text { cellulose }\end{array}$ & Bioplastic & $\begin{array}{l}\text { Laboratory-scale study. An enzymatic } \\
\text { method was used to degrade lignin for } 48 \mathrm{~h} \\
\text { at } 28^{\circ} \mathrm{C} \text { with Phanerochaete chrysosporium } \\
\text { and sieved to a size of } 1000 \text { microns. The } \\
\text { material was sterilized for } 15 \text { min at } 120^{\circ} \mathrm{C} \\
\text { to avoid contamination. }\end{array}$ & $\begin{array}{l}\text { The mechanical properties were } 1.10 \\
\pm 0.15 \mathrm{Mpa} \text { of tension strength, } \\
27.99 \pm 14.72 \% \text { elongation and } 5.26 \\
\pm 1.46 \mathrm{MPa} \text { of elasticity, with } \\
\text { complete biodegradability in } \\
\text { approximately three months. }\end{array}$ & [124] \\
\hline $\begin{array}{l}\text { Pseudo } \\
\text { stems }\end{array}$ & $\begin{array}{c}\text { Musa } \\
\text { paradisiaca } \\
\text { fiber }\end{array}$ & $\begin{array}{c}\text { Biodegradable } \\
\text { utensils }\end{array}$ & $\begin{array}{l}\text { Laboratory-scale study. The fibers extracted } \\
\text { from the pseudostems were subjected to } \\
\text { drying at } 50{ }^{\circ} \mathrm{C} \text { for seven hours. Purification } \\
\text { and bleaching were carried out with } 30 \% \\
\mathrm{NaOH}, \mathrm{NaClO} \text { and water to harden them. } \\
\text { They were then pulverized in a ball mill. }\end{array}$ & $\begin{array}{l}\text { The average net weight of the plates } \\
\text { obtained was } 8.5 \times 10^{-3} \mathrm{~kg} \text {, a plate } \\
\text { dimension of } 156 \mathrm{~mm} \times 14 \mathrm{~mm} \text {. The } \\
\text { average net weight of the vessels } \\
\text { was } 3.3 \times 10^{-3} \mathrm{~kg} \text {, translated into } \\
\text { vessel dimensions of } 69 \mathrm{~mm} \times 81 \\
\text { mm with a capacity of } 175 \mathrm{~mL} \text {. }\end{array}$ & [138] \\
\hline \multirow{3}{*}{$\begin{array}{l}\text { Banana } \\
\text { shells }\end{array}$} & \multirow{3}{*}{$\begin{array}{c}\text { Musa } \\
\text { Paradisiaca } \\
\text { Starch }\end{array}$} & Bioplastic & $\begin{array}{l}\text { Laboratory-scale study. Starch was extracted } \\
\text { from the shells and mixed with } \mathrm{HCl}(0.5 \mathrm{M}) \\
\text { and glycerol. Subsequently, } \mathrm{NaOH} 0.5 \mathrm{~N} \\
\text { was added and spread on a ceramic tile then } \\
\text { placed in the oven at } 120^{\circ} \mathrm{C} \text {. }\end{array}$ & $\begin{array}{l}\text { The bioplastic film can support a } \\
\text { weight close to } 2 \mathrm{~kg} \text { with enough } \\
\text { traction and force. The manufactured } \\
\text { bioplastic can be used as packaging } \\
\text { material or as transport. }\end{array}$ & [128] \\
\hline & & $\begin{array}{l}\text { Polyhydroxyal } \\
\text { kanoate (PHA) }\end{array}$ & $\begin{array}{l}\text { Laboratory-scale study. Banana starch was } \\
\text { added to potential PHA producers such as } \\
\text { Staphylococcus aureus, Geobacillus } \\
\text { stearothermophilus, Bacillus subtilis and Bacillus } \\
\text { siamensis during different incubation times. }\end{array}$ & $\begin{array}{c}\text { Geobacillus stearothermophilus } \\
\text { accumulated } 84.63 \% \text { PHA in } 96 \mathrm{~h} \text {. } \\
\text { Bacillus subtilis accumulated } 71.78 \% \\
\text { PHA in } 24 \text { h of incubation. Bacillus } \\
\text { siamensis accumulated } 77.55 \% \text { and } \\
\text { Staphylococcus aureus about } 70.02 \% \\
\text { PHA in } 24 \text { h of incubation. }\end{array}$ & [139] \\
\hline & & $\begin{array}{c}\text { Biodegradable } \\
\text { planting bag }\end{array}$ & $\begin{array}{l}\text { The shells were cut and oven-dried at } 70^{\circ} \mathrm{C} \text {, } \\
\text { then ground to } 23 \mathrm{~mm} \text { particle size. } \\
\text { Subsequently, they were macerated and } \\
\text { transformed into thermoplastic starch using } \\
\text { eight different mixing concentrations. }\end{array}$ & $\begin{array}{l}\text { The biodegradable plastic degraded } \\
\text { quite quickly, with an average } \\
\text { percentage weight loss of } 65.1 \% \\
\text { within eight weeks. }\end{array}$ & [140] \\
\hline $\begin{array}{c}\text { Banana } \\
\text { shells }\end{array}$ & $\begin{array}{l}\text { Musa } \\
\text { paradisiaca } \\
\text { fomatypica } \\
\text { pectin }\end{array}$ & $\begin{array}{c}\text { Biodegradable } \\
\text { plastic films }\end{array}$ & $\begin{array}{l}\text { The pectin was dissolved in distilled water } \\
\text { and five grams of shell extract was added } \\
\text { and heated to } 60^{\circ} \mathrm{C} \text {. The pectin solution was } \\
\text { then mixed with chitosan and heated to } 80 \\
{ }^{\circ} \mathrm{C} \text { for } 10 \text { min. The mixture was placed in a } \\
\text { mold and dried at } 50-60^{\circ} \mathrm{C} \text {. }\end{array}$ & $\begin{array}{l}\text { The bioplastic had a film thickness } \\
\text { of } 38.7 \mu \mathrm{m} \text {, water-resistance of } 63.63 \\
\% \text {, a tensile strength of } 10.562 \mathrm{MPa} \\
\text { and an elongation value of } 58.33 \% \text {. }\end{array}$ & [141] \\
\hline $\begin{array}{l}\text { Banana } \\
\text { pseudo } \\
\text { stems }\end{array}$ & $\begin{array}{l}\text { Musa spp. } \\
\text { cellulose }\end{array}$ & $\begin{array}{l}\text { Biodegradable } \\
\text { film }\end{array}$ & $\begin{array}{l}\text { The fibers were washed with an } \mathrm{H}_{2} \mathrm{SO}_{4} \\
\text { solution }(2 \mathrm{~g} / \mathrm{L}) \text {, filtered and mixed with } \\
\mathrm{NaOH}(200 \mathrm{~g} / \mathrm{L}) \text { for } 30 \mathrm{~min} \text {. They were then } \\
\text { heated to } 80-90^{\circ} \mathrm{C} \text {, stirring at } 200 \mathrm{rpm} \text { for } \\
\text { four hours to form a cellulose film. }\end{array}$ & $\begin{array}{l}\text { The cellulose film decomposed in } \\
\text { the soil in four weeks, indicating } \\
\text { excellent biodegradability } \\
\text { compared to polystyrene (PE) } \\
\text { plastic films. }\end{array}$ & [142] \\
\hline
\end{tabular}




\subsection{Nanotechnology}

Nanotechnology is a field of vertiginous development in recent years, thanks to the multiple applications in medicine, food, cosmetics and pharmaceuticals, among other fields [143]. The main advantage of nanometric organic substances is their higher ingestionabsorption and better bioavailability in the body, compared to ordinary counterparts on a micro or macroscopic scale [144]. In this sense, lignocellulosic materials are a widely used green alternative to produce materials on a nanometric scale [145]. The smart release of nutrients, the bioseparation of proteins, the rapid sampling of chemical and biological contaminants, the intelligent packaging and the nanoencapsulation of nutraceuticals are emerging nanotechnology topics in the agri-food industry [146].

Some uses of Musaceae waste-losses have been reported, especially cellulose production (Figure 9), while others in the field of materials such as the production of binder-free boards and carbonaceous preforms [147].

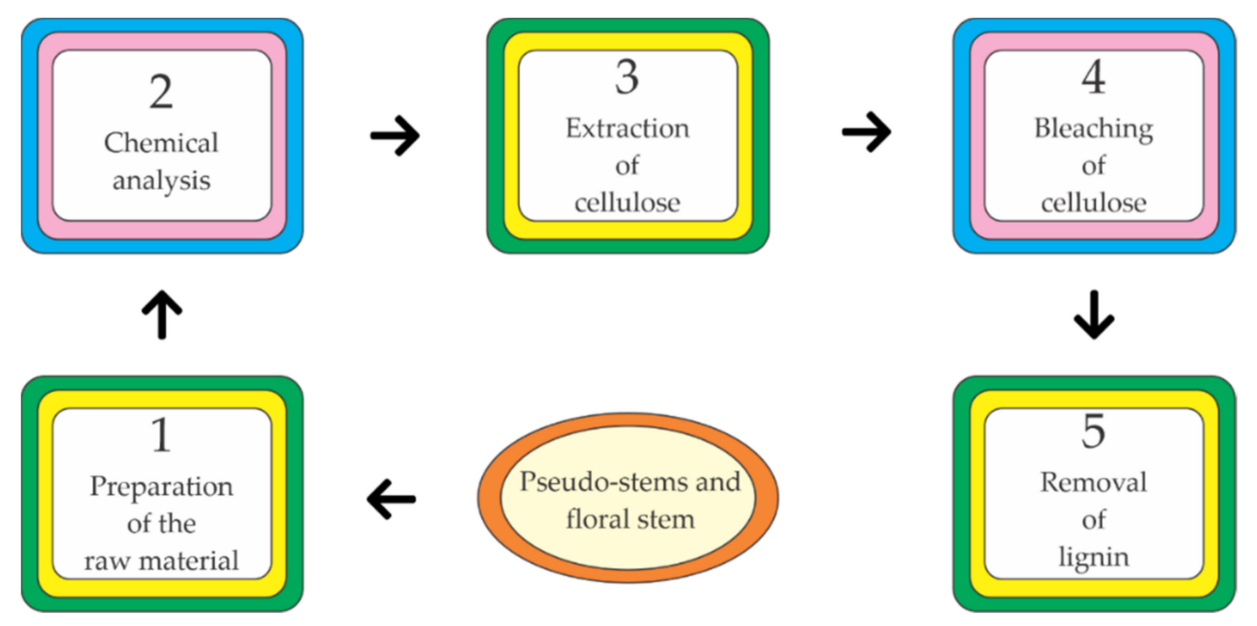

Figure 9. Cellulose extraction from the banana pseudostem and flower stem.

\subsubsection{Cellulose and Nanocellulose}

Cellulose production begins with pseudostems cutting and grounding to reduce their size for the subsequent stages. After that, a chemical analysis is applied to determine the composition of the samples [148]. Then, an alkaline treatment with $\mathrm{NaOH}$ at $15 \% w / v$ for $100 \mathrm{~min}$ under continuous stirring to liberate the cellulose fibers. Cellulose bleaching consists of removing residual lignin using $0.5 \% \mathrm{NaClO}$ for one hour at $70{ }^{\circ} \mathrm{C}$. Finally, the material is washed and dried at $80^{\circ} \mathrm{C}$ [149].

This biopolymer has interesting mechanical properties, including low density, high rigidity, high strength, biodegradability, thermostability and low thermal expansion [150]. Combinations of chemical and mechanical processes have used raw materials to remove non-cellulosic compounds and reduce size [151].

When cellulose has been obtained, it is subjected to shrinking methods to obtain fibers at the nanometric scale, nanocellulose. In this respect, it is claimed that cellulose fibers are produced by subjecting banana residues to various chemical processes, while nanocellulose is the transformation of cellulose at the nanoscale [152]. Nanocellulosic materials can be obtained in cellulose nanofibers (CNFs) or cellulose nanocrystals (CNCs), depending on the extraction procedure. In this process, banana peel and pseudo-stems biomass are used as the direct raw material for the production of nanocellulose [153]. It is possible to find cellulose nanofibrils (CNF) to produce biobased materials. Among its properties are crystallinity, high capacity to form films/nano papers with low thermal expansion, high optical transparency, tensile strength, Young's modulus and barrier (to oil, oxygen and water vapor), in addition to abundancy and non-toxicity [154].

Another alternative to produce nanocellulose is through the use of microorganisms such as Gluconacetobacter xylinus or Medusomyces gisevii. Banana residues are used as a 
food source for the bacteria that produce bacterial nanocellulose (BNC) when the organic substrate (sugar, fructose, glycerol) is polymerized during cultivation $[155,156]$.

Using the bacterium Gluconacetobacter xylinus in fermentation to produce water filter membranes, the synthesis of bacterial nanocellulose (BNC) from Musa paradisiaca (Table 9) was achieved under a $\mathrm{pH} 4.0$, urea at $0.5 \%$ by weight and variable sucrose contents $(5 \%, 10 \%$ and $15 \%(w / v)$ [157]. Additionally, using rotten banana together with Komagataeibacter medellinensis and $26.4 \mathrm{~g} / \mathrm{L}$ of glucose, $16 \mathrm{~g}$ of BNC was obtained after 12 days of fermentation in a plastic bioreactor in Colombia [158]. BNC appears in a twisted band with diameters ranging between $20 \mathrm{~nm}$ and $100 \mathrm{~nm}$ and a micrometer length. Although BNC has the same chemical composition as other types of nanocellulose, BNC exhibits higher purity, water holding capacity and crystallinity, which leads to excellent thermal and mechanical strength [159]. The property of nanocellulose to form liquid crystals is used in various applications, since they retain order when dried. They have been used to make anti-counterfeiting devices, printing inks and iridescent materials [160], and also have applications in the food industry to prepare creams, glazes, sauces, stabilizing oils and fats [161].

Banana residues are not only used to feed microorganisms that produce BNC. This mechanism is also used in various recovery processes, such as obtaining biofuels and producing enzymes. For example, it has been proven that using banana peel as an energy source for Saccharomyces cerevisiae and Cryptococcus sp. makes it possible to produce oleaginous and indigenous yeast with applications in ethanol production and biodiesel, respectively [96,162]. It has been proven that using Saccharomyces sp. and fermented sugar cane inulase can be synthesized using banana peel as substrate. Furthermore, using banana residues as a carbon source for Bacillus subtilis, it is possible to obtain alpha-amylase [163].

\subsubsection{Silver Nanoparticles}

Commercially available silver nanoparticles are synthesized through wet and dry synthesis procedures and approved in consumer products. Many methods have been reported to synthesize silver nanoparticles using chemical, physical, photochemical, green and biological routes [164]. The chemicals used in the chemical synthesis processes are very reactive and can have potentially harmful effects on the handler and the environment and the high cost of production is another factor. This has led to an increase in the focus on green synthesis methods [165]. In green synthesis, the mechanism involved in the production of silver nanoparticles (AgNPs) consists of three steps: reduction, growth and stabilization of silver nanoparticles (Figure 10) [166].

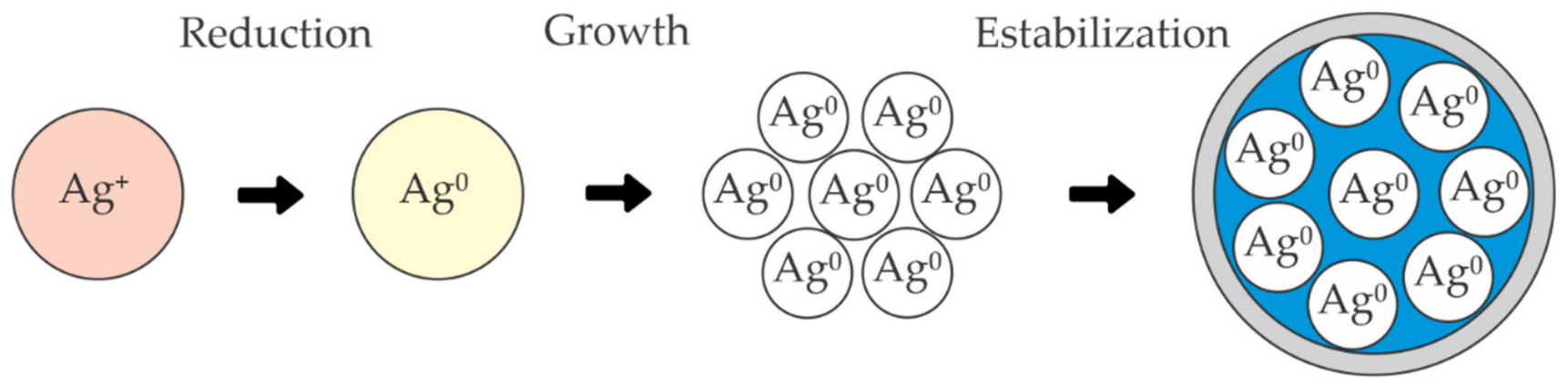

Figure 10. Scheme of the green synthesis of silver nanoparticles. Adapted from [166].

Due to their reductive properties, banana leaves can be used in the organic synthesis of silver nanoparticles. The reducing sugars glucose, fructose and xylose allow Ag+ from the $\mathrm{AgNO}_{3}$ to be reduced and form Ag0, which is stabilized by starch or some other polysaccharides shown in Figure 10. Leaves are pulverized and mixed with $\mathrm{AgNO}_{3}, \mathrm{HCl}, \mathrm{NaOH}$ and $\mathrm{FeCl}_{3}$, for a subsequent Soxhlet-type extraction, then filtered to remove impurities and stored in a refrigerator [167]. Interestingly, some polysaccharides have been used for 
silver nanoparticle synthesis. For example, chitosan, one of the essential polysaccharides, can be used in AgNPs green synthesis as a reducing agent and stabilizing agent. Starch is also used as a capping agent and $\beta$-D-glucose as a reducing agent. Moreover, cellulose and its derivatives and components can reduce and stabilize agents in AgNPs synthesis procedures [168].

Silver nanoparticles have great utility due to their different properties, thanks to their size, optical, magnetic and electrical shape, usually used for coating materials, biosensors, antimicrobial applications, electronic components and composite fibers [169].

\subsubsection{Nano Fertilizers}

The vital interests of the use of nanotechnology in agriculture include specific applications, such as the development of nano fertilizers or nano pesticides to promote the levels of nutrients and increase the productivity of the crop with the decontamination of soils, waters and protection against various insect pests and microbial diseases [170]. Banana peels are crushed and mixed with potassium hydroxide; then, the mixture is filtered and heated up to $70^{\circ} \mathrm{C}$, with continuous stirring at $300 \mathrm{pm}$ for organic fertilizer production [171]. In addition, Williams banana peel has been used to obtain nano fertilizers, obtaining sizes in the range of 19 to $59 \mathrm{~nm}$ (Table 9) [172]. Nano fertilizers improve plant metabolism and nutrient absorption through nanometric pores, facilitated by molecular transporters or nanostructure cuticle pores. An average efficiency gain with the application of nano fertilizers has been verified between 18-29\%, compared to conventional fertilizers [173].

Table 9. Studies on the production and application of nanomaterials from banana processing waste-loss.

\begin{tabular}{|c|c|c|c|c|c|}
\hline Waste & Nanomaterial & $\begin{array}{l}\text { Product or } \\
\text { Application }\end{array}$ & Study & Conclusions & References \\
\hline \multirow[b]{2}{*}{$\begin{array}{c}\text { Musa } \\
\text { Balbisiana } \\
\text { leaves }\end{array}$} & \multirow[b]{2}{*}{$\begin{array}{c}\text { Silver } \\
\text { nanoparticles }\end{array}$} & $\begin{array}{l}\text { Microwave- } \\
\text { assisted } \\
\text { biosynthesis }\end{array}$ & $\begin{array}{l}\text { Laboratory-scale study. Ten milliliters of } \\
\text { banana leaf extract were used in } 40 \mathrm{~mL} \text { of } \\
\text { known concentration }(0.1 \mathrm{mM}) \text { of an } \\
\text { aqueous solution of } \mathrm{AgNO}_{3} . \text { It was then } \\
\text { heated in a microwave to } 160{ }^{\circ} \mathrm{C} \text { and } \\
\text { allowed to dry for one day. }\end{array}$ & $\begin{array}{l}\text { The particle size was in the range of } \\
80-100 \mathrm{~nm} \text {, and they are crystalline. } \\
\text { Nanoparticles were used effectively } \\
\text { in anti-cancer study activities. }\end{array}$ & [167] \\
\hline & & $\begin{array}{l}\text { Green } \\
\text { synthesis }\end{array}$ & $\begin{array}{l}\text { The laboratory-scale study used a } 50 \mathrm{~mL} \\
\text { filtered extract of banana leaves with } 1.0 \\
\mathrm{M} \mathrm{NaOH} \text { and } 10 \mathrm{~mL} \text { silver nitrate. The } \\
\text { mixture was left in a microwave at } 600 \mathrm{~W} \\
\text { for five minutes. }\end{array}$ & $\begin{array}{l}\text { The silver nanoparticles synthesized } \\
\text { by the green method exhibited an } \\
\text { absorption maximum at } 410 \mathrm{~nm} \text {. } \\
\text { Nanoparticle micrographs indicated } \\
\text { spherical silver nanoparticles with a } \\
\text { size range of } 20 \text { to } 300 \mathrm{~nm} \text {. }\end{array}$ & {$[164]$} \\
\hline \multirow{2}{*}{$\begin{array}{c}\text { Musa } \\
\text { Paradisiaca } \\
\text { shells }\end{array}$} & \multirow{2}{*}{$\begin{array}{l}\text { Bacterial } \\
\text { Nanocellu- } \\
\text { lose } \\
(\mathrm{BNC})\end{array}$} & $\begin{array}{l}\text { Flat plate for } \\
\text { desalination }\end{array}$ & $\begin{array}{l}\text { Laboratory-scale study. The membrane } \\
\text { was prepared in three compositions: T1 } \\
\text { (BNC } 60 \% \text {, micro cellulose } 20 \% \text { and silica } \\
\text { 20\%), T2 (BNC 50\%, micro cellulose } 20 \% \\
\text { and silica } 30 \% \text { ) and T3 (BNC } 40 \% \text {, micro } \\
\text { cellulose } 20 \% \text { and silica } 40 \% \text { ). }\end{array}$ & $\begin{array}{l}\text { The T3 membrane had the highest } \\
\text { maximum flux value of } \\
4.41 \times 10^{3} \mathrm{~L} \mathrm{~m}^{-2} \mathrm{~h} \text {. The T2 } \\
\text { membrane had the highest } \\
\text { desalination value of } 4.89 \% \text {. }\end{array}$ & [159] \\
\hline & & $\begin{array}{c}\text { Filter } \\
\text { membrane }\end{array}$ & $\begin{array}{l}\text { Laboratory-scale study where BNC } \\
\text { synthesis was successfully achieved using } \\
\text { the bacterium Gluconacetobacter xylinus in } \\
\text { a fermentation process under pH } 4.0,0.5 \% \\
\text { urea and variable sucrose, } 5 \%, 10 \% \text { and } \\
15 \%(w / v) .\end{array}$ & $\begin{array}{l}\text { The nano-cellular nanofiber } \\
\text { produced from banana peels had } \\
\text { diameter sizes between } 30 \text { and } 50 \mathrm{~nm} \\
\text { applied in water filter membranes. }\end{array}$ & [157] \\
\hline $\begin{array}{l}\text { Banana } \\
\text { Williams } \\
\text { shells }\end{array}$ & $\begin{array}{l}\text { Nanoparticles } \\
\text { extracted } \\
\text { from the shell }\end{array}$ & $\begin{array}{l}\text { Nano } \\
\text { fertilizer }\end{array}$ & $\begin{array}{l}\text { Laboratory-scale study where the shells } \\
\text { were crushed and mixed with potassium } \\
\text { hydroxide; then, the mixture was filtered } \\
\text { and heated up to } 70^{\circ} \mathrm{C} \text {, stirring } \\
\text { continuously at } 300 \mathrm{pm} \text {. Urea and citric } \\
\text { acid were added dropwise until pH 5.0. }\end{array}$ & $\begin{array}{l}\text { The size of the nano-fertilizer } \\
\text { constituents ranged from } 19 \text { to } 55 \\
\text { nm. Nanoparticle sizes of } 40 \mathrm{~nm} \\
\text { and } 55 \mathrm{~nm} \text { were obtained. }\end{array}$ & {$[171]$} \\
\hline
\end{tabular}


Table 9. Cont.

\begin{tabular}{|c|c|c|c|c|c|}
\hline Waste & Nanomaterial & $\begin{array}{c}\text { Product or } \\
\text { Application }\end{array}$ & Study & Conclusions & References \\
\hline $\begin{array}{l}\text { Musa spp. } \\
\text { Shells and } \\
\text { pseu- } \\
\text { dostem }\end{array}$ & Nanosilica & $\begin{array}{l}\text { Composite } \\
\text { polymer }\end{array}$ & $\begin{array}{l}\text { Laboratory-scale study. The samples were } \\
\text { made by pouring a mixture into an open } \\
\text { mold. Curing was carried out at room } \\
\text { temperature under pressure. Banana } \\
\text { fibers ( } 5 \text { wt. \%) were used with } 0.1 \text { wt. } \% \text { of } \\
\text { nano-silica fillers. }\end{array}$ & $\begin{array}{l}\text { The polymer had a density between } \\
0.8-1.5 \mathrm{~g} / \mathrm{cm}^{3} \text { and a hardness of } \\
50-92 \text { on the Rockwell scale. }\end{array}$ & [174] \\
\hline \multirow{2}{*}{$\begin{array}{l}\text { Musa spp. } \\
\text { husk, } \\
\text { canola } \\
\text { straw and } \\
\text { buffalo } \\
\text { manure }\end{array}$} & $\begin{array}{l}\text { Zero Valent } \\
\text { Nano iron } \\
\text { (nZVI) }\end{array}$ & $\begin{array}{l}\text { Ecological } \\
\text { synthesis }\end{array}$ & $\begin{array}{l}\text { Laboratory-scale study. Shell extract was } \\
\text { used to reduce Fe ions. Five milliliters of } \\
\text { filtered extract were mixed with } 5 \mathrm{~mL} \text { of } \\
\text { freshly prepared } 1.0-5.0 \mathrm{mM} \text { aqueous } \\
\text { solution of FeSO } \mathrm{Fith}_{4} \text { withstant stirring at } \\
\text { room temperature. }\end{array}$ & $\begin{array}{l}\text { The formation of nanoparticles } \\
\text { could be observed by UV-Visible } \\
\text { spectroscopy at a wavelength of } \\
150-550 \mathrm{~nm} \text {. The optimal } \\
\text { concentration for the synthesis of } \\
\text { nZVI was } 1.0 \mathrm{mM} \mathrm{Fe}^{2+} \text { ions. }\end{array}$ & [175] \\
\hline & $\begin{array}{c}\mathrm{Fe}_{3} \mathrm{O}_{4} \\
\text { nanoparticles }\end{array}$ & $\begin{array}{l}\text { Methane } \\
\text { production }\end{array}$ & $\begin{array}{c}\text { Laboratory-scale study. } \mathrm{Fe}_{3} \mathrm{O}_{4} \text { was added } \\
\text { in five different doses }(0.4,0.5,0.81,1.22 \\
\text { and } 1.63 \mathrm{mg} \text { ) in two proportions of straw: } \\
\text { manure }(40: 60) \text { and waste-loss of banana: } \\
\text { manure (60:40), based on } 5 \mathrm{~g} \text { of volatile } \\
\text { solids (VS). }\end{array}$ & $\begin{array}{l}\text { A methane yield of } 256.0 \\
\mathrm{mLCH}_{4} / \mathrm{gVS} \text { and } 202.3 \\
\mathrm{mLCH}_{4} / \mathrm{gVS} \text { was obtained for } \\
\text { straw: manure and banana: } \\
\text { manure, respectively. }\end{array}$ & [176] \\
\hline $\begin{array}{l}\text { Musa spp. } \\
\text { pseudo } \\
\text { stems }\end{array}$ & $\begin{array}{l}\text { Nanocellulose } \\
\text { fiber (FNC) }\end{array}$ & $\begin{array}{l}\text { Soluble } \\
\text { packing } \\
\text { material }\end{array}$ & $\begin{array}{l}\text { Laboratory-scale study. Nanocellulose } \\
\text { was used together with polyvinyl alcohol } \\
\text { (PVOH). The PVOH was added in a Baker } \\
\text { with thermostat at } 80^{\circ} \mathrm{C} \text { and FNC was } \\
\text { added in different amounts }(1,2 \text { and } 5 \mathrm{~g}) \text {. } \\
\text { Then, ultrasound treatment for one hour. }\end{array}$ & $\begin{array}{l}\text { The solubility of the package was } \\
94.57 \% \text {. The tension strength was } \\
2.36 \mathrm{~kg} \text { f and Young's model of } \\
59.16 \mathrm{~N} \cdot \mathrm{mm}^{-2} \text {. }\end{array}$ & [177] \\
\hline
\end{tabular}

\subsection{Organic Fertilizers}

Organic fertilizers can be defined as a product of the natural decomposition of organic matter by fermentation processes, which varies according to the type of fertilizer to be prepared. The degradation occurs naturally through the air, the sun, microorganisms and water [178]. Organic fertilizers come from composting organic compounds mediated by microorganisms, improving soil quality and providing nutrients to crops, thus reducing chemical fertilizer use and the undesirable polluting factors production $[179,180]$. Composting systems can be classified depending on the level of aeration in the open-air system, semi-open system and confined system, where the latter is ideal for controlling aeration [181]. Banana peels are rich in micronutrients, suggesting their use to improve soil quality and crop yields, either through their use as an organic soil conditioner or to produce compost to meet specific plant requirements [182]. To obtain the cake, the remains of banana leaves and pseudostems are subjected to endogenous hydrolysis, extraction and neutralization processes. Subsequently, aerobic degradation leads to compost [183].

Composting is done by the layered pile method (Figure 11), with an approximate volume of $1 \mathrm{~m}^{3}$. Banana waste-loss is cut and mixed with organic matter for its subsequent degradation process. Water is sprinkled over compost piles to keep the mix moist, with approximately 50\% moisture content [184]. The process takes about twelve weeks when the core temperature of the material is close to the air temperature. During this period, the composting material is mixed at least once a week to avoid excessive temperatures from the beginning of the process [185]. The application of this type of fertilizer improves the structure of the soils allowing better absorption of nutrients such as $\mathrm{N}, \mathrm{P}$ and $\mathrm{K}$ by the plants [186]. Compost eliminates harmful bacteria and fungi, neutralizes $\mathrm{pH}$, improves soil texture and improves water retention. Soils with applied compost adsorb better nutrients that benefit plants, thus creating healthier and nutrient-rich foods [187]. 


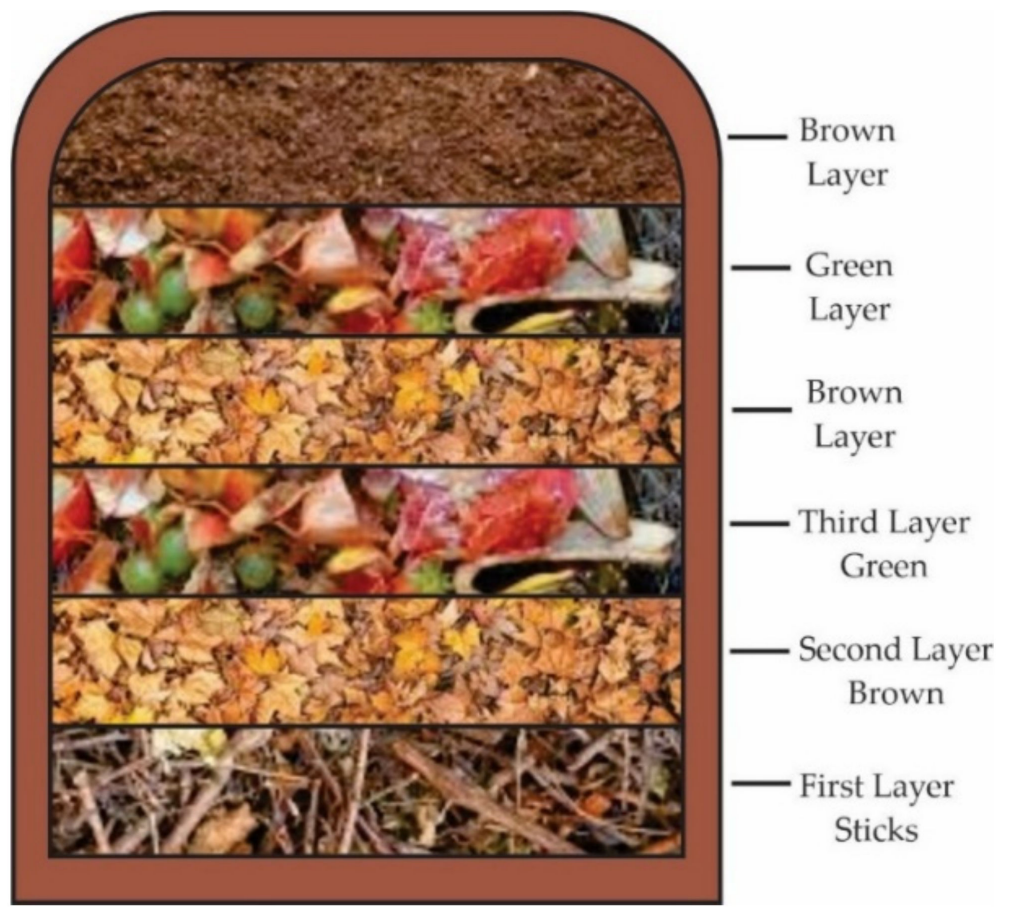

Figure 11. The layering of the compost pile.

Bokashi is one of the most used organic fertilizers for the improvement and fertility of soils. The production process is short and includes many materials such as chicken manure, black earth, ash or coal. Bokashi's color is grayish, with sand apparency [188]. Before mixing the ingredients, the waste-loss (including peels and pseudostems) are chopped until obtaining particles of approximately 2 to $5 \mathrm{~cm}$. After that, particles are scattered and left to dry in the shade for three days. The earth is sieved to exclude any foreign material such as stones, sticks, or other foreign materials [189]. Molasses is diluted with water, just like bread yeast. The materials are grouped in layers to effect mixing, forming a trapezoidal mound or pile. Subsequently, they are turned to homogenize the components until they form a mound again with a height of approximately $90 \mathrm{~cm}$ [190].

The bokashi can be obtained easily and quickly. The soil application also favors plants and is an excellent source of nutrients for vegetation. In addition, it improves water uptake and increases resistance against erosion [191]. This fertilizer constitutes a sustainable alternative with a profitable production that improves crop productivity, maintains good soil quality and efficiently manages available resources [192].

Vermicomposting (VC) involves the biodegradation of organic matter by worms to maintain the flow of nutrients from one system to another [193]. There are several studies on the use of vermicomposting to produce organic fertilizers (Table 10).

Decomposition begins in the gizzards of earthworms, where organic matter is digested. Earthworms can accumulate heavy metals, contaminating organisms and increasing microorganisms' resource availability by crushing the waste into smaller particles [194]. Organic waste, such as the peel, leaves and pseudostems from bananas, is crushed and spread in layers exposed to sunlight for five to ten days to eliminate pathogenic microorganisms and harmful gases [195]. The banana leaves are valuable organic material because worms can transform them into humus, allowing nutrient transfer to the soil [196]. Among essential parameters for vermicomposting, humidity and temperature are controlled by spraying water on the bed, keeping the temperature at $35^{\circ} \mathrm{C}$ and humidity between 50 and $60 \%$. The solid waste is weighed and placed in a container, then sprayed with water to hydrate it to within 50-65\% humidity. After that, earthworms are introduced into the solid waste for the decomposition process [197]. The mixture is then covered to protect the worms from sunlight [198]. 
When used as a fertilizer, VC positively impacts soil quality, plant growth, crop yield and nutritional value. The use of VC in the soil also improves physicochemical characteristics (aggregation, stability, $\mathrm{pH}$, apparent density and water retention capacity) [199]. Likewise, vermicomposting contributes nutrients to the soil such as nitrogen, phosphorus and potassium, allowing an increase in the productivity of crops [200].

Table 10. Studies on the production of organic fertilizers from banana waste-loss.

\begin{tabular}{|c|c|c|c|c|}
\hline Waste & Technique & Study & Conclusions & References \\
\hline \multirow{2}{*}{$\begin{array}{l}\text { Pine } \\
\text { sawdust } \\
\text { and peels of } \\
\text { mango and } \\
\text { Musa spp. }\end{array}$} & \multirow{2}{*}{ Bokashi } & $\begin{array}{l}\text { The beds or piles were prepared in a greenhouse. } \\
\text { The ingredients were incorporated in the following } \\
\text { vertical order: } 0.2 \mathrm{~m} \text { of organic vegetable waste, } 0.1 \\
\text { m of manure, a sheet of lime, } 0.1 \mathrm{~m} \text { of forest soil, } \\
\text { charcoal, and again } 0.2 \mathrm{~m} \text { of plant waste-loss. }\end{array}$ & $\begin{array}{l}\text { It was observed that the } \mathrm{pH} \text { ranged from } 7.9 \\
\text { to } 8.4 \text {, which corresponds to modern alkaline. } \\
\text { Fermentation lasted } 60 \text { days with a } \\
\text { maximum of } 30.6 \% \text { organic matter. }\end{array}$ & [192] \\
\hline & & $\begin{array}{c}\text { The waste-loss were mixed in a } 1: 1: 1 \text { ratio and the } \\
\text { mixture was homogenized. The piles were turned } \\
\text { daily for the first ten days to maintain the } \\
\text { temperature of } 70{ }^{\circ} \mathrm{C} \text {. The decomposition process } \\
\text { lasted } 21 \text { days. }\end{array}$ & $\begin{array}{l}\text { The Bokashi presented electrical conductivity } \\
\text { of } 8.97 \mathrm{mhos} / \mathrm{cm} \text {, the potassium content of } \\
4.3 \mathrm{mg} / \mathrm{kg} \text { of bokashi and sodium content of } \\
161.0 \mathrm{mg} / \mathrm{kg} \text {, thanks to the Bokashi content } \\
\text { of the banana pulp. }\end{array}$ & [201] \\
\hline \multirow{3}{*}{$\begin{array}{l}\text { Fruit peels, } \\
\text { Pseudo } \\
\text { stems and } \\
\text { leaves of } \\
\text { Musa } \\
\text { Paradisiaca }\end{array}$} & \multirow{3}{*}{$\begin{array}{l}\text { Vermicom } \\
\text { posting }\end{array}$} & $\begin{array}{l}\text { The shredded waste was spread in layers and } \\
\text { exposed to sunlight for ten days; then, they were } \\
\text { doused with water to hydrate them. The } \\
\text { earthworm Eudrilus eugeniae was introduced into } \\
\text { the solid waste-loss ratio of 5:1 (g/earthworm). }\end{array}$ & $\begin{array}{l}\text { The best result in the chemical composition } \\
\text { of the prepared vermicompost was } 17.21 \% \text { of } \\
\text { nitrogen, } 10.24 \% \text { of phosphorus, } 48.32 \% \text { of } \\
\text { potassium and a carbon-bond-nitrogen ratio } \\
\text { of } 29 \text {, promising for its application in crops. }\end{array}$ & [195] \\
\hline & & $\begin{array}{l}\text { Banana pseudo stems were enriched with cow } \\
\text { manure in different proportions using Eisenia fetida. } \\
\text { A humidity level of } 60 \% \text { was maintained } \\
\text { throughout the process. }\end{array}$ & $\begin{array}{l}\text { The chemical analysis showed a gradual } \\
\text { increase in plant nutrients such as } \mathrm{P}, \mathrm{Ca}, \mathrm{K}, \\
\mathrm{Mg} \text { and Fe. The total transformation of the } \\
\text { raw material lasted } 60 \text { days. }\end{array}$ & [198] \\
\hline & & $\begin{array}{l}\text { Banana waste-loss and mango litter were mixed } \\
\text { separately with dry and powdered cow manure } \\
\text { (40\% cow manure and } 60 \% \text { organic waste) for } 30 \\
\text { days under a shady place. Then, Eudrilus eugeniae } \\
\text { and Eisenia foetida were added to finish the process. }\end{array}$ & $\begin{array}{l}\text { Banana waste was a better substrate than } \\
\text { mango litter in terms of time required for } \\
\text { composting, amount of compost produced } \\
\text { and conversion percentage. }\end{array}$ & [202] \\
\hline \multirow{2}{*}{$\begin{array}{l}\text { Municipal } \\
\text { waste, peel } \\
\text { and pulp of } \\
\text { Musa spp. }\end{array}$} & \multirow{2}{*}{ Compost } & $\begin{array}{l}\text { In total, nine containers (170 L) were filled, } \\
\text { containing } 50 \mathrm{~kg} \text { of solid waste. Microorganisms } \\
\text { were inoculated together with cow manure and } \\
\text { waste-loss were cut into small } 2 \mathrm{~cm} \text { pieces. The } \\
\text { leachate was made through holes in the bottom of } \\
\text { the containers. }\end{array}$ & $\begin{array}{l}\text { The final product had nutrient values of } \\
\mathrm{N}-2.13 \%, \mathrm{P}-0.57 \%, \mathrm{~K}-7.68 \%, \mathrm{Ca}-16,000 \\
\mathrm{mg} / \mathrm{kg}, \mathrm{Mg}-14,600 \mathrm{mg} / \mathrm{kg}, \mathrm{Iron}-113 \\
\mathrm{mg} / \mathrm{Kg}, \mathrm{Cu}-89 \mathrm{mg} / \mathrm{kg} \text { and } \mathrm{Zn}-154 \mathrm{mg} / \mathrm{kg} \text {, } \\
\text { as well as lower concentration of } \\
\text { heavy metals. }\end{array}$ & [203] \\
\hline & & $\begin{array}{l}\text { Hermetia illucens was used with a banana peel } \\
\text { pre-treatment to improve the composting process. } \\
\text { The shells were homogenized in a blender and } \\
\text { subsequently mixed with ethanol, methanol, } \\
\text { chloroform and nitrogen. }\end{array}$ & $\begin{array}{l}\text { The mixture containing nitrogen produced } \\
\text { the highest final weight of larvae (134 mg). } \\
\text { Pre-treatment increases the waste to biomass } \\
\text { conversion ratio. }\end{array}$ & [204] \\
\hline
\end{tabular}

\section{Conclusions}

The banana industry generates a large amount of waste-loss that can be used in various recovery processes, such as biofuels, wastewater treatment and the production of bioplastics focused on implementing a circular economy. Due to its high content of organic compounds rich in carbon such as polysaccharides, banana peel has been used mainly to obtain bioplastics with high degradation rates, and produce biofuels such as diesel and ethanol. The leaves from the banana plant are used to produce biodegradable packaging and utensils and organic fertilizers. Due to their fibrous composition, the banana's pseudostems are used to obtain bioplastics requiring little time for biodegradation. Cellulose and hemicellulose banana waste-loss content is of great importance in nanotechnological processes, especially in producing green nanoparticles. It has been shown that the leaves, rachis, pseudostems and banana peel have a high potential for use, which can be reused in various recovery processes. In addition, it allows to close production cycles and reduce the accumulation of waste from the banana industry through its use in different applications, contributing to the growth of the circular economy. 
Despite the wide range of application possibilities for banana industry waste, production techniques must be improved to obtain products with better characteristics, such as improving the biofuel process's pre-treatment technique to produce more energy-efficient end products. However, the lack of pilot-scale studies and the industrial implementation of these wastes is evident, suggesting the need for more studies at higher-scale applications. We cannot forget that companies seek to innovate their productive activities to obtain products with added value every day. For that reason, it is necessary to implement the various possibilities exhibited in this review to add value to the banana industry in a sustainable way, contributing to a circular economy.

Author Contributions: Conceptualization, C.D.G.-T., S.A.A., Á.J.D.C. and E.F.-L.; formal analysis, C.D.G.-T., S.A.A. and Á.J.D.C.; investigation, C.D.G.-T., S.A.A. and Á.J.D.C.; methodology, C.D.G.-T., S.A.A. and Á.J.D.C.; project administration, C.D.G.-T. and E.F.-L.; supervision, C.D.G.-T.; writingoriginal draft, C.D.G.-T., S.A.A. and Á.J.D.C.; and writing-review and editing, S.A.A., Á.J.D.C., E.F.-L. and C.D.G.-T. All authors have read and agreed to the published version of the manuscript.

Funding: This research has been funded by Dirección General de Investigaciones of Universidad Santiago de Cali under call No. 01-2021.

Institutional Review Board Statement: Not applicable.

Informed Consent Statement: Not applicable.

Data Availability Statement: Not applicable.

Conflicts of Interest: The authors declare no conflict of interest.

Sample Availability: Not applicable.

\section{References}

1. Osorio, L.L.D.R.; Flórez-López, E.; Grande-Tovar, C.D. The Potential of Selected Agri-Food Loss and Waste to Contribute to a Circular Economy: Applications in the Food, Cosmetic and Pharmaceutical Industries. Molecules 2021, 26, 515. [CrossRef] [PubMed]

2. Major Tropical Fruits Market Review 2019. Rome. Available online: http://www.fao.org/publications/card/es/c/CB0834EN/ (accessed on 2 July 2021).

3. Chala, K.; Yetenayet, T. Assessment of banana fruit handling practices and associated fungal pathogens in Jimma town market, southwest Ethiopia. Food Sci. Nutr. 2018, 6, 609-616. [CrossRef]

4. Sidhu, J.; Zafar, T. Bioactive compounds in banana fruits and their health benefits. Food Qual. Saf. 2018, 2, 183-188. [CrossRef]

5. Mele, L.; Bidault, G.; Mena, P.; Crozier, A.; Brighenti, F.; Vidal-Puig, A.; Del Rio, D. Dietary (poly)phenols, brown adipose tissue activation and energy expenditure: A narrative review. Adv. Nutr. 2017, 8, 694-704. [CrossRef]

6. Sobiesiak, M. Phenolic Compounds-Natural Sources, Importance and Applications. In Phenolic Compounds-Natural Sources, Importance and Applications; Soto, M., Palma, M., Garcia, M., Eds.; InTech: Rijeka, Croatia, 2017; pp. 3-13.

7. Vu, H.; Scarlett, C.; Vuong, Q. Phenolic compounds within banana peel and their potential uses: A review. J. Funct. Foods 2018, 40, 238-248. [CrossRef]

8. Leading Producers of Bananas Worldwide in 2019, by Country (in 1000 Metric Tons). Available online: https: / / www.statista. $\mathrm{com} /$ statistics/811243/leading-banana-producing-countries/ (accessed on 22 July 2021).

9. Zhiminaicela, J.; Quevedo, J.; García, R. Banana Production in the Provincial of El Oro and Its Impact on Agrobiodiversity. Rev. Metrop. Cienc. Apl. 2020, 3, 189-195.

10. Analysis of Banana Exports in the Multipartes Commercial Framework between Ecuador and the European Union. Available online: https:/ / www.eumed.net/rev/oel/2020/05/analisis-exportaciones-banano.html (accessed on 22 July 2021).

11. Leading Countries of Destination of Banana Exported from Colombia in 2019. Available online: https://www.statista.com/ statistics/1054606/exports-banana-value-colombia-country-destination/ (accessed on 22 July 2021).

12. Bananas Exports by Country 2019. Available online: https://www.worldstopexports.com/bananas-exports-country/ (accessed on 8 April 2021).

13. Banana Market Review 2019. Rome. Available online: http://www.fao.org/publications/card/es/c/CB0168EN/ (accessed on 2 July 2021).

14. Fresh Plaza. Banana Exports Down 18.3\% in Philippines Due to Low Production. Available online: https:/ /www.freshplaza. com/article/9294147/banana-exports-down-18-3-in-philippines-due-to-low-production/ (accessed on 22 July 2021).

15. Food Outlook-Biannual Report on Global Food Markets. Available online: http://www.fao.org/documents/card/es/c/cb1993en/ (accessed on 3 July 2021). 
16. Jian, S.; Xuemei, H.; Yayuan, T.; Jie, T.; Zhichun, L. Research Progress of Banana Processing. Chin. J. Trop. Crop. 2020, 41, $2022-2033$. [CrossRef]

17. García, R.; Quevedo, J.; Socorro, A. Practices for the use of solid waste in banana plantations and results of its implementation. Univ. Soc. 2020, 12, 280-291.

18. Kumar, G.; Singh, Y.; Mishra, S.; Rahangdale, H. Potential Use of Banana and Its By-products: A Review. Int. J. Curr. Microbiol. Appl. Sci. 2018, 7, 1827-1832. [CrossRef]

19. Yusof, N.; Yusoff, M. Investigation of Chemical Analysis and Physical Properties of Bio-polymer Waste Banana Peel Fibre Composite. IOP Conf. Ser. Earth Environ. Sci. 2020, 596, 12-42. [CrossRef]

20. Chakraborty, R.; Sabruna, S.; Roy, R.; Majumdar, S.; Roy, S. Banana pseudostem substitution in wheat flour biscuits enriches the nutritional and antioxidative properties with considerable acceptability. SN Appl. Sci. 2021, 3, 1-12. [CrossRef]

21. Chaitali, C.; Arunima, M.; Bornini, B.; Shubham, M.; Bandyopadhyay, K. Utilization of Banana Peel and Pulp As a Functional Ingredient in Product Development: A Review. Eng. Res. Sci. Technol. 2017, 6, 137-148.

22. Morseletto, P. Targets for a circular economy. Resour. Conserv. Recycl. 2020, 153, 1-12. [CrossRef]

23. Vilariño, M.; Franco, C.; Quarrington, C. Food loss and waste reduction as an integral part of a circular economy. Front. Environ. Sci. 2017, 5, 1-5. [CrossRef]

24. Prieto-sandoval, V.; Jaca, C.; Ormazabal, M. Towards a consensus on the circular economy. J. Clean. Prod. 2018, 179, 605-615. [CrossRef]

25. Korhonen, J.; Honkasalo, A.; Seppälä, J. Circular Economy: The Concept and its Limitations. Ecol. Econ. 2018, 143, 37-46. [CrossRef]

26. Selvaggi, R.; Valenti, F. Assessment of fruit and vegetable residues suitable for renewable energy production: GIS-based model for developing new frontiers within the context of circular economy. Appl. Syst. Innov. 2021, 4, 10. [CrossRef]

27. Geng, Y.; Sarkis, J.; Bleischwitz, R.; Sarkis, J.; Bleischwitz, R. How to globalize the circular economy. Nat. Comment 2019, 565, 153-155. [CrossRef] [PubMed]

28. Schroeder, P.; Anggraeni, K.; Weber, U. The Relevance of Circular Economy Practices to the Sustainable Development Goals. J. Ind. Ecol. 2019, 23, 77-95. [CrossRef]

29. Amini, A.; Birch, J.; Bekhit, A. Production, application and health effects of banana pulp and peel flour in the food industry. J. Food Sci. Technol. 2019, 56, 548-559. [CrossRef]

30. Ahmad, T.; Danish, M. Prospects of banana waste utilization in wastewater treatment: A review. J. Environ. Manag. 2018, 206, 330-348. [CrossRef]

31. Tapia, C.; Paredes, N.; Lima, L. Diversity representativeness of the genus musa in Ecuador. ECUADOR ES CALIDAD 2019, 6, 53-58. [CrossRef]

32. Aguirre, J.; Castaño, V. Starch rheological characterization and morphological evaluation of 20 varieties of Musaceae (Musa sp.), from Fedeplatano Germplasm Bank, Chinchiná-Caldas, Colombia. Acta Agron. 2016, 65, 218-225. [CrossRef]

33. Diagram of Banana Plant [CCO]. Available online: https://www.flickr.com/photos/iita-media-library/5828333849/in/ photostream/ (accessed on 18 July 2021).

34. Amarasinghe, N.; Thilakarathna, G.; Wickramasinghe, I.; Wijesekara, I.; Deyalage, S. Functional, Physicochemical and antioxidant properties of flour and cookies fromtwo different banana varieties. Int. J. Food Sci. 2021, 2021, 1-9. [CrossRef]

35. Torres, L.; Zamora, L. Benefits in Latin America and the Caribbean about production of Cavendish AAA banana resistant to black Sigatoka. Rev. Bionatura 2018, 3, 740-744. [CrossRef]

36. Salvacion, A. Effect of climate on provincial-level banana yield in the Philippines. Inf. Process. Agric. 2020, 7, 50-57. [CrossRef]

37. Aguilar-Hawod, K.; Cumagun, C. Genetic diversity of Fusarium oxysporum f. sp. cubense causing Panama wilt of banana in the Philippines. Pathogens 2020, 9, 32. [CrossRef] [PubMed]

38. Lucas, J.; Velásquez, J.; Quintero, V. Evaluation of the thermal properties and composition starch extracted from 26 varieties of musa. Vitae 2016, 1, 551-556.

39. Siji, S.; Nandini, P. Chemical and Nutrient Composition of Selected Banana Varieties of Kerala. Int. J. Adv. Eng. Manag. Sci. 2017, 3, 401-404. [CrossRef]

40. Kookal, S.; Thimmaiah, A. Nutritional Composition of Staple Food Bananas of Three Cultivars in India. Am. J. Plant. Sci. 2018, 9 , 2480-2493. [CrossRef]

41. Escobar, H.; Andrade, J. Preliminary survey, diversity and population density of mites in banana, Musa AAA (Cavendish subgroup) cv. Williams in Peru. Int. J. Acarol. 2021, 47, 170-173. [CrossRef]

42. Laeliocattleya, R.A.; Estiasih, T.; Griselda, G.; Muchlisyiyah, J. The bioactive compounds and antioxidant activity of ethanol and ethyl ecetate extracts of Candi Banana (Musa paradisiaca). IOP Conf. Ser. Earth Environ. Sci. 2018, 131, 012013. [CrossRef]

43. Elayabalan, S.; Subramaniam, S.; Shobana, V.; Ashok Kumar, K. An Overview on Phytochemical Composition of Banana (Musa spp.). Int. Bimon. Indian J. Nat. Sci. 2017, 7, 12408-12419.

44. Rinah, N.; Adewale, O.; Tonna, A.; Jideani, A. Banana Bioactives: Absorption, Utilisation and Health Benefits. Intech 2019, 32, 137-144.

45. Oyeyinka, B.; Afolayan, A. Comparative evaluation of the nutritive, mineral and antinutritive composition of Musa sinensis L. (banana) and Musa paradisiaca L. (plantain) fruit compartments. Plants 2019, 8, 598. [CrossRef]

46. Qamar, S.; Shaikh, A. Therapeutic potentials and compositional changes of valuable compounds from banana-A review. Trends Food Sci. Technol. 2018, 79, 1-9. [CrossRef] 
47. Quiceno, M.; Giraldo, G.; Villamizar, R. Physical-chemical characterization of plantain (Musa paradisiaca sp. AAB, Simmonds) for industrialization. UGCiencia 2014, 20, 48-54.

48. Sanlier, N.; Bektesoglu, M. Migraine and Biogenic Amines. Ann. Med. Health Sci. Res. 2021, 1362-1371.

49. Medina, S.; Collado, J.; Ferreres, F.; Londoño, J.; Jiménez, C.; Guy, A.; Durand, T.; Galano, J.-M.; Gil, A. Valorization Strategy of Banana Passion Fruit Shell Wastes: An Innovative Source of Phytoprostanes and Phenolic Compounds and Their Potential Use in Pharmaceutical and Cosmetic Industries. J. Food Nutr. Res. 2017, 5, 801-808. [CrossRef]

50. Bakar, S.; Ahmad, N.; Jailani, F. Chemical and Functional Properties of Local Banana Peel Flour. J. Food Nutr. Res. 2018, 6, 492-496. [CrossRef]

51. Pareek, S. Nutritional and biochemical composition of banana (Musa spp.) cultivars. Nutr. Compos. Fruit Cultiv. 2016, 9, 49-81.

52. Falcomer, A.; Riquette, R.; De Lima, B.; Ginani, V.; Zandonadi, R. Health benefits of green banana consumption: A systematic review. Nutrients 2019, 11, 1222. [CrossRef] [PubMed]

53. Pyar, H.; Peh, K. Chemical compositions of banana peels (Musa sapientum) fruits cultivated in Malaysia using proximate analysis. Res. J. Chem. Environ. 2018, 22, 108-113.

54. Yesmin, B.; Sankar, D. Chemical profiling and functional properties of dietary fibre rich inner and outer bracts of culinary banana flower. J. Food Sci. Technol. 2019, 56, 5298-5308. [CrossRef]

55. Huang, S.; Martinez, M.; Bohrer, B. The compositional and functional attributes of commercial flours from tropical fruits (breadfruit and banana). Foods 2019, 8, 586. [CrossRef] [PubMed]

56. Šeremet, D.; Durgo, K.; Jokić, S.; Hudek, A.; Cebin, A.; Mandura, A.; Jurasović, J.; Komes, D. Valorization of banana and red beetroot peels: Determination of basic macrocomponent composition, application of novel extraction methodology and assessment of biological activity in vitro. Sustainability 2020, 12, 4539. [CrossRef]

57. Sánchez, S.; Comas, O.; Rabell, J.; Veciana, T.; Latorre, L.; Vidal, C. Biogenic amines in plant-origin foods: Are they frequently underestimated in low-histamine diets? Foods 2018, 7, 205. [CrossRef] [PubMed]

58. Alavudeen, A.; Rajini, N.; Karthikeyan, S.; Thiruchitrambalam, M.; Venkateshwaren, N. Mechanical properties of banana/kenaf fiber-reinforced hybrid polyester composites: Effect of woven fabric and random orientation. Mater. Des. 2015, 66, $246-257$. [CrossRef]

59. Pauline, M.; Alexandre, O.; Andoseh, B.K.; Abeline, M.T.S.; Agatha, T. Production technique and sensory evaluation of traditional alcoholic beverage based maize and banana. Int. J. Gastron. Food Sci. 2017, 10, 11-15. [CrossRef]

60. Maryati, T.; Pertiwiningrum, A.; Bachruddin, Z. The Effects of Tanning with Kepok Banana (Musa paradisiaca L) Bunch on the Physical Quality of Rabbit Skin. Int. J. Recent Technol. Eng. 2019, 8, 12564-12567. [CrossRef]

61. Bhushan, S.; Rana, M.S.; Nandan, N.; Prajapati, S.K. Energy harnessing from banana plant wastes: A review. Bioresour. Technol. Rep. 2019, 7, 100212. [CrossRef]

62. Codex alimentarious standard for bananas. Codex Stan 2005, 205, 1-5.

63. Haro Velasteguí, A.; Borja Arévalo, A.; Triviño Bloisse, S. Analysis on the use of banana waste, as raw material for the production of biodegradable plastic materials. Dominio Las Cienc. 2017, 3, 506-525.

64. Sharma, R.; Oberoi, H.S.; Dhillon, G.S. Fruit and Vegetable Processing Waste: Renewable Feed Stocks for Enzyme Production. In Agro-Industrial Wastes as Feedstock for Enzyme Production; Academic Press: Cambridge, MA, USA, 2016; pp. 23-59. [CrossRef]

65. Tibolla, H.; Pelissari, F.; Martins, J.; Vicente, A.; Menegalli, F. Cellulose nanofibers produced from banana peel by chemical and mechanical treatments: Characterization and cytotoxicity assessment. Food Hydrocoll. 2018, 75, 192-201. [CrossRef]

66. Mahindrakar, K.; Rathod, V. Utilization of banana peels for removal of strontium (II) from water. Environ. Technol. Innov. 2018, 11, 371-383. [CrossRef]

67. Danmaliki, G.; Muhammad, A.; Shamsuddeen, A.; Usman, B. Bioethanol Production from Banana Peels. IOSR J. Environ. Sci. 2016, 10, 56-62. [CrossRef]

68. Romelle, F.D.; Rani, P.A.; Manohar, R.S. Chemical Composition of Some Selected Fruit Peels. Eur. J. Food Sci. Technol. $2016,4,12-21$.

69. Leonel, M.; Bolfarini, A.C.B.; da Silva, R.M.J.; Souza, J.M.A.; Leonel, S. Banana fruits with high content of resistant starch: Effect of genotypes and phosphorus fertilization. Int. J. Biol. Macromol. 2020, 150, 1020-1026. [CrossRef]

70. Kusuma, S.A.F.; Febriyanti, M.; Farzadillah, N. Natural oral anti-dysentery from pseudostem of klutuk (Musa balbisiana colla) and kepok (Musa paradisiaca L.) Banana plant from Indonesia. J. Pharm. Sci. Res. 2018, 10, 2443-2447.

71. Arafat, K.; Nayeem, J.; Quadery, A.; Quaiyyum, M.; Jahan, M.S. Handmade paper from waste banana fibre. Bangladesh J. Sci. Ind. Res. 2018, 53, 83-88. [CrossRef]

72. Aboul-Enein, A.; Salama, Z.; Gaafar, A.; Aly, H.; Bou-Elella, F.; Ahmed, H. Identification of phenolic compounds from banana peel (Musa paradaisica L.) as antioxidant and antimicrobial agents. J. Chem. Pharm. Res. 2016, 8, 46-55.

73. Guerrero, A.; Ballesteros, I.; Ballesteros, M. The potential of agricultural banana waste for bioethanol production. Fuel 2018, 213, 176-185. [CrossRef]

74. Wang, C.; Muhammad, A.; Liu, Z.; Huang, B.; Cao, B. Effects of ensiling time on banana pseudo-stem silage chemical composition, fermentation and in Sacco rumen degradation. J. Anim. Plant. Sci. 2016, 26, 339-346.

75. Martins, A.; Pasquali, M.; Schnorr, C.; Martins, J.; De Araújo, G.; Rocha, A. Development and characterization of blends formulated with banana peel and banana pulp for the production of blends powders rich in antioxidant properties. J. Food Sci. Technol. 2019, 56, 5289-5297. [CrossRef] 
76. Poveda, C.; Galeas, G. Evaluation of banana waste (masa acuminata cavendish subgroup) and cocoa (theobroma cacao), through the production of compost and biol. 3C Tecnol. Glosas Innov. Apl. Pyme 2020, 9, 17-29. [CrossRef]

77. Suárez, B.; Fernández, E.; Méndez, G.; Soto, D. Operational principles of circular economy for sustainable development: Linking theory and practice. J. Clean. Prod. 2019, 214, 952-961. [CrossRef]

78. Rada, E. Special waste valorization and renewable energy generation under a circular economy: Which priorities? WIT Trans. Ecol. Environ. 2019, 222, 145-157. [CrossRef]

79. Sharma, P.; Gaur, V.; Sirohi, R.; Varjani, S.; Hyoun, S.; Wong, J. Sustainable processing of food waste for production of bio-based products for circular bioeconomy. Bioresour. Technol. 2021, 325, 124684. [CrossRef]

80. Gumisiriza, R.; Hawumba, J.; Okure, M.; Hensel, O. Biomass waste-to-energy valorisation technologies: A review case for banana processing in Uganda. Biotechnol. Biofuels 2017, 10, 1-29. [CrossRef] [PubMed]

81. Zhang, Y.; Gao, Z.; Song, N.; Li, X. High-performance supercapacitors and batteries derived from activated banana-peel with porous structures. Electrochim. Acta 2016, 222, 1257-1266. [CrossRef]

82. Rezania, S.; Oryani, B.; Cho, J.; Talaiekhozani, A.; Sabbagh, F.; Hashemi, B.; Rupani, P.; Mohammadi, A. Different pretreatment technologies of lignocellulosic biomass for bioethanol production: An overview. Energy 2020, 199, 117457. [CrossRef]

83. Romero, H.; Macías, C.; Palacios, A.; Redrovan, F. Kinetic study of bioethanol production from agroindustrial residues of ripe banana peel. Ind. Data 2019, 22, 187-202. [CrossRef]

84. Adrianzen, F.P.C. Elaboración y Caracterización del Etanol a Partir de Residuos Industriales de Banano. Bachelor's Thesis, Universidad Cesar Vallejo, Piura, Perú, 2018.

85. Smuga, M.; Piskier, T.; Walendzik, B.; Szymanowska, D. Assessment of wasteland derived biomass for bioethanol production. Electron. J. Biotechnol. 2019, 41, 1-8. [CrossRef]

86. Romero, H.; Gadvay, K.; Castillo, A. Potencial biotecnológico y bioeconómico de residuos lignocelulósicos de la agroindustria del banano. Conf. Proc. 2017, 1, 695-705.

87. Durán, D. Aprovechamiento Energético de la Codigestión Anaeróbica de la Fracción Orgánica de Residuos Sólidos Urbanos y Residuos de Cosecha de Plátano Para la Producción de Biogás. Master's Thesis, Universidad Nacional de Colombia, Bogotá, Colombia, 2020.

88. Tsapekos, P.; Kougias, P.; Angelidaki, I. Mechanical pretreatment for increased biogas production from lignocellulosic biomass; predicting the methane yield from structural plant components. Waste Manag. 2018, 78, 903-910. [CrossRef] [PubMed]

89. Sahar, S.; Rúnar, U.; Richter, C. Hydrogen production via biomass gasification: Simulation and performance analysis under different gasifying agents. Biofuels 2021, 1, 1-18.

90. Batyrova, K.A. Sustainability of Biohydrogen Production Using Engineered Algae as a Source. In Biohydrogen Production: Sustainability of Current Technology and Future Perspective; Singh, A., Rathore, D., Eds.; Springer: New Delhi, India, 2016 ; p. 333. ISBN 9788132235774.

91. Dincer, I.; Acar, C. Smart energy solutions with hydrogen options. Int. J. Hydrogen Energy 2018, 43, 8579-8599. [CrossRef]

92. Ramos, M.; Dias, A.; Puna, J.; Gomes, J.; Bordado, J. Biodiesel production processes and sustainable raw materials. Energies 2019, 12, 4408. [CrossRef]

93. Avhad, M.; Marchetti, J. Innovation in solid heterogeneous catalysis for the generation of economically viable and ecofriendly biodiesel: A review. Sci. Eng. 2016, 58, 157-208. [CrossRef]

94. Laskar, I.; Deshmukhya, T.; Biswas, A.; Paul, B.; Changmai, B.; Gupta, R.; Chatterjee, S.; Rokhum, S. Utilization of Biowastederived Catalyst for Biodiesel Production: Process Optimization Using Response Surface Methodology and Particle Swarm Optimization Method. ChemRxiv 2020, 1, 1-5. [CrossRef]

95. Balajii, M.; Niju, S. Banana peduncle-A green and renewable heterogeneous base catalyst for biodiesel production from Ceiba pentandra oil. Renew. Energy 2020, 146, 2255-2269. [CrossRef]

96. Han, S.; Kim, G.Y.; Han, J.I. Biodiesel production from oleaginous yeast, Cryptococcus sp. by using banana peel as carbon source. Energy Reports 2019, 5, 1077-1081. [CrossRef]

97. Al-Mohammedawi, H.; Znad, H.; Eroglu, E. Improvement of photofermentative biohydrogen production using pre-treated brewery wastewater with banana peels waste. Int. J. Hydrogen Energy 2019, 44, 2560-2568. [CrossRef]

98. Navarro-Mtz, A.K.; Urzúa-Valenzuela, M.; Morelos-Pedro, M.A.; Roldan-Sabino, C.; Quintana-Melgoza, J.M.; Kakazey, M.; Juarez-Arellano, E.A. Hydrogen production from non-conventional biomass pyrolysis. Inorg. Chem. An. Indian J. 2017, 12, 1-10.

99. Te, W.Z.; Muhanin, K.; Chu, Y.M.; Selvarajoo, A.; Singh, A.; Ahmed, S.; Vo, D.V.N.; Show, P.L. Optimization of Pyrolysis Parameters for Production of Biochar From Banana Peels: Evaluation of Biochar Application on the Growth of Ipomoea aquatica. Front. Energy Res. 2021, 8, 1-16. [CrossRef]

100. Sial, T.A.; Khan, M.N.; Lan, Z.; Kumbhar, F.; Ying, Z.; Zhang, J.; Sun, D.; Li, X. Contrasting effects of banana peels waste and its biochar on greenhouse gas emissions and soil biochemical properties. Process. Saf. Environ. Prot. 2019, 122, 366-377. [CrossRef]

101. Uribe, R.; Smith, L.; Osorio, G.; Beatriz, B. Evaluation of activated carbon obtained from banana rachis in the purification of water intended for human consumption. Inst. Edwards Deming 2020, 1, 41-67.

102. Pardo, S.; Karina, D.; Moncada, V. Evaluation of natural coagulants in water clarification. Rev. Investig. Agrar. Ambient. 2020, 11, 105-116.

103. Valladares, M.; Valerio, C.; De la cruz, P.; Melgosa, R. Non-conventional absorbers: Sustainable alternatives for wastewater treatment. Rev. Ing. Univ. Medellín 2017, 16, 55-73. [CrossRef] 
104. Davila, T.; Benitez, R.; Sanchez, N.; Ordoñes, D.; Muños, J. Evaluation of agroindustrial waste as bio-filters: Removal of cr (vi) in tannery synthetic effluents. Biotecnol. Sect. Agropecu. Agroind. 2017, 15, 49-58.

105. Wang, B.; Sun, Y.; Sun, R. Fractionational and structural characterization of lignin and its modification as biosorbents for efficient removal of chromium from wastewater: A review. J. Leather Sci. Eng. 2019, 1, 1-25. [CrossRef]

106. Peng, H.; Guo, J. Removal of chromium from wastewater by membrane filtration, chemical precipitation, ion exchange, adsorption electrocoagulation, electrochemical reduction, electrodialysis, electrodeionization, photocatalysis and nanotechnology: A review. Environ. Chem. Lett. 2020, 18, 2055-2068. [CrossRef]

107. Payel, S.; Sarker, M. Banana Rachis Charcoal To Remove Chromium From Tannery Wastewater. In Proceedings of the 4th International Conference on Civil Engineering for Sustainable Development, Khulna, Bangladesh, 9-11 February 2018.

108. Okologume, W.; Olayiwola, R. Treatment of Produced Oilfield Water by Adsorption Using Banana Peel as Adsorbent. Int. J. Eng. Trends Technol. 2019, 67, 66-69. [CrossRef]

109. Rodrigues, C.; Benvenuti, T.; Da Trinidade, C.; Siqueira, M.; Zoppas, J.; Pérez, V.; Moura, A. Electrodialysis for the tertiary treatment of municipal wastewater: Efficiency of ion removal and ageing of ion exchange membranes. Angew. Chem. Int. Ed. 2018, 6, 5855-5869.

110. Sijabat, E.; Nuruddin, A.; Aditiawati, P.; Purwasasmita, B. Synthesis and Characterization of Bacterial Nanocellulose from Banana Peel for Water Filtration Membrane Application. J. Phys. Conf. Ser. 2019, 1230, 012085. [CrossRef]

111. Hawal, L.; Al-Zubaidi, L.; Allah, S. Electro-Kinetic Remediation of Nickel from Contaminated Soil Using Bio remedies Banana Peels and Surfactant-Enhanced. J. Ecol. Eng. 2021, 22, 214-220. [CrossRef]

112. Priyatharishini, M.; Mohktar, N.; Risky, K. Study on the Effectiveness of Banana Peel Coagulant in Turbidity Reduction of Synthetic Wastewater. Int. J. Eng. Technol. Sci. 2019, 6, 82-90.

113. Leff, T.; Stemmer, P.; Tyrrell, J.; Jog, R. Diabetes and exposure to environmental lead (Pb). Toxics 2018, 6, 54. [CrossRef]

114. Afolabi, F.; Musonge, P.; Bakare, B. Evaluation of lead (Ii) removal from wastewater using banana peels: Optimization study. Polish J. Environ. Stud. 2021, 30, 1487-1496. [CrossRef]

115. Luc, A.; Guill, A.; Rivas, R.; Akle, V.; Cruz, J.; Osma, J. Functionalization and Evaluation of Inorganic Adsorbents for the Removal of Cadmium in Wastewater. Molecules 2021, 26, 4150. [CrossRef]

116. Kristianto, H. The Potency of Indonesia Native Plants as Natural Coagulant: A Mini Review. Water Conserv. Sci. Eng. 2017, 2, 51-60. [CrossRef]

117. Kakoi, B.; Kaluli, J.; Ndiba, P.; Thiong'o, G. Banana pith as a natural coagulant for polluted river water. Ecol. Eng. 2016, 95, 699-705. [CrossRef]

118. Zaman, B.; Sutrisno, E.; Cahyani, F.; Raharyani, D. Banana Tree as Natural Biofilter for Organic Contaminant in Wastewater Treatment. IOP Conf. Ser. Earth Environ. Sci. 2020, 448, 012031. [CrossRef]

119. Prastuti, O.; Septiani, E.; Kurniati, Y.; Setyawan, H. Banana peel activated carbon in removal of dyes and metals ion in textile industrial waste. Mater. Sci. Forum 2019, 966, 204-209. [CrossRef]

120. Mouiya, M.; Bouazizi, A.; Abourriche, A.; Benhammou, A.; El Hafiane, Y.; Ouammou, M.; Abouliatim, Y.; Younssi, S.; Smith, A.; Hannache, H. Fabrication and characterization of a ceramic membrane from clay and banana peel powder: Application to industrial wastewater treatment. Mater. Chem. Phys. 2019, 227, 291-301. [CrossRef]

121. Daud, Z.; Suhani, N.; Mohamed, R.; Awang, H. Feasibility of banana (Musa sapientum) trunk biofibres for treating kitchen wastewater. Nat. Environ. Pollut. Technol. 2017, 16, 1205-1210.

122. Antonieta, M.; Palma, R. Obtaining bioplastics from agricultural waste: A review of the Ecuador's potentialities. Av. Quim. 2018, $13,69-78$.

123. Antonio, F.; Auccahuasi, S.; Huamán, C.; Chipa, H.; Elizabeth, M.; Chacón, C. Biodegradability of bioplastics made from Mangifera indica and Musa paradisiaca peels. Cent. Agric. 2020, 47, 22-31.

124. Jiménez, C. Evaluación de Polímeros en Pseudotallos de Musa acuminata AAA, Musa sapientum ABB y Musa paradisiaca AAB Para Elaboración de Bioplástico. Master's Thesis, El Colegio de la Frontera Sur, San Cristóbal, Mexico, 2017.

125. Manali, S.; Sanjukta, R.; Himanshu, P.; Archana, M. Bioplastic for future: A review then and now. World J. Adv. Res. Rev. 2021, 9 , 056-067. [CrossRef]

126. Ekiert, M.; Mlyniec, A.; Uhl, T. The influence of degradation on the viscosity and molecular mass of poly(lactide acid) biopolymer. Diagnostyka 2015, 16, 63-70.

127. Shafqat, A.; Al-Zaqri, N.; Tahir, A.; Alsalme, A. Synthesis and characterization of starch based bioplatics using varying plant-based ingredients, plasticizers and natural fillers. Saudi J. Biol. Sci. 2021, 28, 1739-1749. [CrossRef]

128. Jaikishan, C.; Sai, C. Production of bioplastic from banana peels. Int. J. Adv. Sci. Eng. Technol. 2018, 6, 36-38.

129. Azieyanti, N.; Amirul, A.; Othman, S.; Misran, H. Mechanical and Morphology Studies of Bioplastic-Based Banana Peels. J. Phys. Conf. Ser. 2020, 1529, 032091. [CrossRef]

130. Barreto, N.; Gama, Z.; Mamede, N. Development and Characterization of Polyhydroxybutyrate and Banana Fiber biocomposites. Matéria 2018, 23. [CrossRef]

131. McAdam, B.; Fournet, M.; McDonald, P.; Mojicevic, M. Production of polyhydroxybutyrate (PHB) and factors impacting its chemical and mechanical characteristics. Polymers 2020, 12, 2908. [CrossRef]

132. Rajan, K.; Thomas, S.; Gopanna, A. Polyhydroxybutyrate (PHB): A Standout Biopolymer for Environmental Sustainability. Handb. Ecomater. 2017, 1-23. [CrossRef] 
133. Mabazza, K.; Requiso, P.; Alfafara, C.; Nayve, F.; Ventura, J. Steam explosion and sequential steam explosion-Dilute acid pretreatment optimization of banana pseudostem for polyhydroxybutyrate (Phb) production. Philipp. J. Sci. 2020, 149, $259-271$.

134. Yeo, J.; Muiruri, J.; Thitsartarn, W.; Li, Z.; He, C. Recent advances in the development of biodegradable PHB-based toughening materials: Approaches, advantages and applications. Mater. Sci. Eng. C 2018, 92, 1092-1116. [CrossRef]

135. Scaffaro, R.; Maio, A.; Sutera, F.; Gulino, E.; Morreale, M. Degradation and recycling of films based on biodegradable polymers: A short review. Polymers 2019, 11, 651. [CrossRef] [PubMed]

136. Ayala, B.; Chavéz, J.; Quito, R.; Rojas, J.; Ruiz, D. Diseño de una Planta Para la Elaboración de Envases Biodegradables a Base de Arrocillo y Hojas de Banano. Bachelor's Thesis, Universidad De Piura, Piura, Perú, 2020.

137. Zapata, D.; Ludeña, A.; Trasmonte, W.; Cabrejos, E. Biofilm from green banana starch (Musa paradisiaca) and cassava (Manihot esculenta). Rev. Cient. Pakamuros 2020, 8, 15-30. [CrossRef]

138. Aguiar, S.; Garcia, M.; Vallejo, S. Design and elaboration of biodegradable utensils from the fiber of the banana stem (Musa paradisiaca) as an alternative of use to mitigate environmental impacts caused by the plastic. Cienc. Digit. Editor. 2020, 4, 373-384. [CrossRef]

139. Vijay, R.; Tarika, K. Banana peel as an inexpensive carbon source for microbial polyhydroxyalkanoates (PHA) production. Int. Res. J. Env. Sci 2018, 7, 1-8.

140. Huzaisham, N.; Marsi, N. Utilization of banana (Musa paradisiaca) peel as bioplastic for planting bag application. Int. J. Adv. Res. Eng. Technol. 2020, 11, 108-118. [CrossRef]

141. Chodijah, S.; Husaini, A.; Zaman, M. Extraction of Pectin from Banana Peels (Musa Paradiasica Fomatypica) for Biodegradable Plastic Films. J. Phys. Conf. Ser. 2019, 1167, 012061. [CrossRef]

142. Binling, A.; Zheng, L.; Wenqui, L.; Zheng, X.; Yang, Y.; Xiao, D.; Shi, J.; Sheng, Z. Biodegradable cellulose film prepared from banana pseudo-stem using an ionic liquid for mango presevation. Front. Plant Sci. 2021, 12, 234. [CrossRef]

143. Gómez, C.; Serpa, A.; Velásquez, J.; Gañán, P.; Castro, C.; Vélez, L.; Zuluaga, R. Vegetable nanocellulose in food science: A review. Food Hydrocoll. 2016, 57, 178-186. [CrossRef]

144. Hugo, R.; Saldivar, L.; Argüello, B.; Villarreal, G.; Reyes, V. Nanotechnology potential in sustainable agriculture. Acta Univ. 2018, 28, 9-24. [CrossRef]

145. Ávalos, A.; Haza, A.; Morales, P. Nanotechnology in the Food Industry. Rev. Complut. Cienc. Vet. 2016, 10, 1-17. [CrossRef]

146. Jain, S.; Mehata, M.S. Medicinal Plant Leaf Extract and Pure Flavonoid Mediated Green Synthesis of Silver Nanoparticles and their Enhanced Antibacterial Property. Sci. Rep. 2017, 7, 1-13. [CrossRef]

147. Naeem, M.; Siddiqui, Q.; Mushtaq, M.; Farooq, A.; Pang, Z.; Wei, Q. Insitu Self-Assembly of Bacterial Cellulose on Banana Fibers Extracted from Peels. J. Nat. Fibers 2020, 17, 1317-1328. [CrossRef]

148. Shreedhana, K.; Ilavarasi, R. Fabrication of nanocrystalline cellulose from banana peel obtained from unripe plantain bananas. J. Phys. Conf. Ser. 2020, 1644, 012002. [CrossRef]

149. Paramasivam, S.; Panneerselvam, D.; Sundaram, D.; Shiva, K.; Subbaraya, U. Extraction, Characterization and Enzymatic Degumming of Banana Fiber. J. Nat. Fibers 2020, 1-10. [CrossRef]

150. Balea, A.; Fuente, E.; Concepcion Monte, M.; Merayo, N.; Campano, C.; Negro, C.; Blanco, A. Industrial application of nanocelluloses in papermaking: A review of challenges, technical solutions and market perspectives. Molecules 2020, 25, 526. [CrossRef]

151. Gabriel, E.; García, J.; Rodríguez, K. Production the nanofiber of cellulose from banana rachis. Geosci. Eng. 2019, 62, 18-21.

152. Harini, K.; Ramya, K.; Sukumar, M. Extraction of nano cellulose fibers from the banana peel and bract for production of acetyl and lauroyl cellulose. Carbohydr. Polym. 2018, 201, 329-339. [CrossRef]

153. Farinas, C.; Marconcini, J.; Mattoso, L. Enzymatic conversion of sugarcane lignocellulosic biomass as a platform for the production of ethanol, enzymes and nanocellulose. J. Renew. Mater. 2018, 6, 203-216. [CrossRef]

154. Maria, B.; Guimarães, R.; Martins, M. Bio-based films/nanopapers of banana tree pseudostem: From lignocellulosic wastes to added- value micro/nanomaterials. Res. Sq. 2021. [CrossRef]

155. Abdullah, N.; Rani, M.; Mohammad, M.; Sainorudin, M.; Asim, N.; Yaakob, Z.; Razali, H.; Emdadi, Z. Nanocellulose from agricultural waste as an emerging nanotechnology material for nanotechnology applications-An overview. Polimery/Polymers 2021, 66, 157-168. [CrossRef]

156. Shavyrkina, N.; Budaeva, V.; Skiba, E.; Mironova, G.; Bychin, N.; Gismatulina, Y.; Kashcheyeva, E.; Sitnikova, A.; Shilov, A.; Kuznetsov, P.; et al. Scale-up of biosynthesis process of bacterial nanocellulose. Polymers 2021, 13, 20. [CrossRef] [PubMed]

157. Sijabat, E.; Nuruddin, A.; Aditiawati, P.; Purwasasmita, B. Optimization on the synthesis of bacterial nano cellulose (BNC) from banana peel waste for water filter membrane applications. Mater. Res. Express 2020, 7, 055010. [CrossRef]

158. Molina, C.; Álvarez, J.; Zuluaga, R.; Castro, C.; Gañán, P. A novel approach using conventional methodologies to scale up bnc production using komagataeibacter medellinensis and rotten banana waste as alternative. Processes 2020, 8, 469. [CrossRef]

159. Sijabat, E.K.; Nuruddin, A.; Aditiawati, P.; Purwasasmita, B. Flat sheet membrane composite for desalinisation applications based on Bacterial Nanocellulose (BNC) from banana peel waste, cellulose and silica. Mater. Res. Express 2020, 7, 105004. [CrossRef]

160. Djalia, T.; Tarchoun, A.; Derradji, M.; Hamidon, T. Nanocellulose From Fundamentals to Advanced Applications Enhanced. Front. Chem. 2020, 8, 392. [CrossRef]

161. Ruiz, C. Design, Preparation and Analytical Applications of Nanocellulose and Its Derivatives. Master's Thesis, Universidad de Córdoba, Córdoba, Spain, 2017. 
162. Matharasi, A.; Uma, C.; Sivagurunathan, P.; Sampathkumar, P. Determination of bioethanol potential from banana waste using indigenous yeast (Saccharomyces cerevisiae. KX033583). J. Pharmacogn. Phytochem. 2018, 7, 2041-2047.

163. Ravindran, R.; Hassan, S.; Williams, G.; Jaiswal, A. A review on bioconversion of agro-industrial wastes to industrially important enzymes. Bioengineering 2018, 5, 93. [CrossRef] [PubMed]

164. Ul, S.; Khan, H.; Khan, S.; Mariam, A. Green synthesis of colloidal silver using banana (Musa balbisiana) leaf extract. J. Pharmacogn. Phytochem. 2019, 8, 622-625.

165. Lee, S.H.; Jun, B.H. Silver nanoparticles: Synthesis and application for nanomedicine. Int. J. Mol. Sci. 2019, 20, 865. [CrossRef] [PubMed]

166. Mohammadlou, M.; Maghsoudi, H.; Jafarizadeh, H. A review on green silver nanoparticles based on plants: Synthesis, potential applications and eco-friendly approach. Int. Food Res. J. 2016, 23, 446-463.

167. Narasimha, R.; Hublikar, L.; Patil, S.; Bhat, P. Microwave assisted biosynthesis of silver nanoparticles using banana leaves extract: Phytochemical, spectral characterization and anticancer activity studies. J. Water Environ. Nanotechnol. 2021, 6, 49-61. [CrossRef]

168. Srikar, S.; Giri, D.; Pal, D.; Mishra, P.; Upadhyay, S. Green Synthesis of Silver Nanoparticles: A Review. Green and Sustainable Chemistry. Green Sustain. Chem. 2016, 6, 34-56. [CrossRef]

169. Thangadurai, D.; Naik, J.; Sangeetha, J.; Shettar, A.; Adetunji, J.B. Nanomaterials from Agrowastes: Past, Present and the Future. Handb. Nanomater. Nanocomposites Energy Environ. Appl. 2020, 471-487. [CrossRef]

170. Prasad, R.; Bhattacharyya, A.; Nguyen, Q.D. Nanotechnology in sustainable agriculture: Recent developments, challenges and perspectives. Front. Microbiol. 2017, 8, 1-13. [CrossRef] [PubMed]

171. Hussein, H.; Shaarawy, H.; Hussien, N.; Hawash, S. Preparation of nano-fertilizer blend from banana peels. Bull. Natl. Res. Cent. 2019, 43, 1-9. [CrossRef]

172. Sharmila, C.; Subramanian, K.; Lakshmanan, A. Nanofertilizer in enhancing the production potencials of crops. In Nanotechnology in Plant Growth Promotion and Protection-Google Libros; Avinash, P., Ed.; John Wiley \& Sons Ltd.: New York, NY, USA, 2021; pp. 63-66.

173. Usman, M.; Farooq, M.; Wakeel, A.; Nawaz, A.; Cheema, S.; Rehman, H.; Ashraf, I.; Sanaullah, M. Nanotechnology in agriculture: Current status, challenges and future opportunities. Sci. Total Environ. 2020, 721, 137778. [CrossRef]

174. Rahul, K.; Madhukar, S.; Karthik, M.; Pavana, K.; Kenneth, P.; Loyd, D. Processing and Characterisation of Banana Fiber Reinforced Polymer Nano Composite. Nanosci. Nanotechnol. 2017, 7, 34-37. [CrossRef]

175. Kane, S.; Mishra, A.; Dutta, A.K. Ecofriendly Synthesis of nano Zero Valent Iron from Banana Peel Extract. J. Phys. Conf. Ser. 2016, 795, 012063. [CrossRef]

176. Noonari, A.; Mahar, R.; Sahito, A.; Brohi, K. Anaerobic co-digestion of canola straw and banana plant wastes with buffalo dung: Effect of Fe3O4 nanoparticles on methane yield. Renew. Energy 2019, 133, 1046-1054. [CrossRef]

177. Patel, B.; Joshi, P. Banana Nanocelluse Fiber/PVHO composite film as soluble packaging material: Preparation and characterization. Packag. Technol. Res. 2020, 4, 95-101. [CrossRef]

178. Sudharmaidevi, C.R.; Thampatti, K.C.M.; Saifudeen, N. Rapid production of organic fertilizer from degradable waste by thermochemical processing. Int. J. Recycl. Org. Waste Agric. 2017, 6, 1-11. [CrossRef]

179. Ramírez, E. Management of local organic resources, as an agroecological strategy for the development of fertilizers, in cloud forests of the coastal mountain range Venezuela. Soil Sci. 2017, 45, 19-30. [CrossRef]

180. Ayilara, M.; Olanrewaju, O.; Babalola, O.; Odeyemi, O. Waste management through composting: Challenges and potentials. Sustainability 2020, 12, 4456. [CrossRef]

181. Lim, L.; Bong, C.; Lee, C.; Klemeš, J.; Sarmidi, M.; Lim, J. Review on the current composting practices and the potential of improvement using two-stage composting. Chem. Eng. Trans. 2017, 61, 1051-1056. [CrossRef]

182. El Barnossi, A.; Moussaid, F.; Iraqi, A. Tangerine, banana and pomegranate peels valorisation for sustainable environment: A review. Biotechnol. Reports 2021, 29, e00574. [CrossRef]

183. Guevara, C.; José, A.; Carlos, P. Biorefinery from banana rejected: Integrated system for ethanol, single cell protein, biogas and compost co-prod. Biotecnol. Sect. Agropecu. Agroind. 2016, 14, 78-86. [CrossRef]

184. Virk, A.; Memon, K.; Memon, M.; Hussain, S. Formulation of optimum banana residue based compost product and its efficacy on maize and soil properties. Indian J. Sci. Technol. 2021, 14, 932-941. [CrossRef]

185. Jędrczak, A. Composting and Fermentation of Biowaste-Advantages and Disadvantages of Processes. Civ. Environ. Eng. Rep. 2018, 28, 71-87. [CrossRef]

186. Yu, Z.; Tang, J.; Liao, H.; Liu, X.; Zhou, P.; Chen, Z.; Rensing, C.; Zhou, S. The distinctive microbial community improves composting efficiency in a full-scale hyperthermophilic composting plant. Bioresour. Technol. 2018, 265, 146-154. [CrossRef] [PubMed]

187. Candis, H.; Dana, W.; Melanie, P.; Matthew, G.; Michelle, K. Safe Community Gardening Practices: Focus Groups with Garden Leaders in Atlanta, Georgia. Physiol. Behav. 2020, 176, 139-148. [CrossRef]

188. Lasmini, S.; Nasir, B.; Hayati, N.; Edy, N. Improvement of soil quality using bokashi composting and NPK fertilizer to increase shallot yield on dry land. Aust. J. Crop. Sci. 2018, 12, 1743-1749. [CrossRef]

189. Faozi, K.; Yudono, P.; Indradewa, D.; Maas, A. Banana Stem Bokashi and its Effect to Increase Soybean Yield (Glycine max L. Merrill) in Coastal Sands Area. Agrotechnology 2018, 7, 1-7. [CrossRef]

190. Marín, D. Impact of the Use of Biofertilizers Based on Organic Waste in Soils. Concienc. Tecnol. 2019, 58, 1-10. 
191. Ginting, S. Promoting Bokashi as an Organic Fertilizer in Indonesia: A Mini Review. Int. J. Environ. Sci. Nat. Resour. 2019, 21, 142-144. [CrossRef]

192. Loarte, L.; Apolo, V.; Alvarez, P. Effect of maturation time and efficient microorganisms on the bocashi nutritional quality. Cedemaz 2018, 8, 30-36.

193. Gupta, C.; Prakash, D. Role of Vermicomposting in Agricultural Waste Management. In Sustainable Green Technologies for Environmental Management; Sneh, G., Nazareno, M., Eds.; Springer: Singapore, 2019; pp. 283-295. ISBN 9789811327728.

194. Grasserová, A.; Hanc, A.; Innemanová, P.; Cajthaml, T. Composting and vermicomposting used to break down and remove pollutants from organic waste: A mini review. Eur. J. Environ. Sci. 2020, 10, 9-14. [CrossRef]

195. Mahmud, A.; Yusuf, M.; Ahmed, A.; Ado, D.; Adamu, Y. Studies on conversion of solid waste to bioferilizer by vermicomposting. Trends Sci. Technol. J. 2019, 4, 137-139. [CrossRef]

196. Firdous, J.; Bharathi, V.; Devi, S.; Jayachitra, J. Enzymatic analysis and effect of vermicompost production from banana leaves waste using epigeic earthworm eudrillus euginea. Nat. Environ. Pollut. Technol. 2019, 18, 1305-1311.

197. Thakur, A.; Kumar, A.; Kumar, C.; Kiran, B.; Kumar, S.; Athokpam, V. A review on vermicomposting: By-products and its importance. Plant. Cell Biotechnol. Mol. Biol. 2021, 22, 156-164.

198. Khatua, C.; Sengupta, S.; Krishna, V.; Kundu, B.; Chakraborti, A.; Tripathi, S. Dynamics of organic matter decomposition during vermicomposting of banana stem waste using Eisenia fetida. Waste Manag. 2018, 79, 287-295. [CrossRef]

199. Piya, S.; Shrestha, I.; Gauchan, D.; Lamichhane, J. Vermicomposting in organic Agriculture: Influence on the soil nutrients and plant growth. Int. J. Res. 2018, 5, 1055-1063.

200. Kamalraj, R.; Nandhivarman, M.; Thongni, P.; Pradheeps, M.; Poyyamoli, G. Utilization of agrowastes for vermicomposting and its impact on growth and reproduction of selected earthworm species in Puducherry, India. Nat. Environ. Pollut. Technol. 2017, 16, 1125-1133.

201. Mendivil, C.; Nava, E.; Armenta, A.; Félix, A. Elaboration of an organic fertilizer type bocashi and its evaluation on germination and growth of radish. Rev. Cienc. Biol. Salud Mex. 2019, 22, 17-23.

202. Vidya, G.; Sakthivel, P.; Alice, R.P. Bio-conversion of banana waste (Pseudostem and leaves) and mango leaf litter into vermicompost by Eudrilus eugeniae and Eisenia foetida. Entomol. Zool. Stud. 2020, 8, 1529-1534.

203. Devi, E.; Mugilvannan, R. Enhanced Composting of Market Waste using Effective Microorganisms. Eng. Technol. 2018, 5, 645-652.

204. Isibika, A.; Vinnerås, B.; Kibazohi, O.; Zurbrügg, C.; Lalander, C. Pre-treatment of banana peel to improve composting by black soldier fly (Hermetia illucens (L.), Diptera: Stratiomyidae) larvae. Waste Manag. 2019, 100, 151-160. [CrossRef] [PubMed] 